\title{
SWEATING IT OUT: FACILITATING CORRECTIONS AND PAROLE IN CANADA THROUGH ABORIGINAL SPIRITUAL HEALING
}

\section{David Milward*}

Aboriginal peoples continue to be subjected to drastic overincarceration. Much of the existing literature explores contemporary adaptations of Aboriginal justice traditions that resemble restorative justice as a solution. There is by comparison a lack of literature that considers searching for solutions during the correctional phase of the justice system, after Aboriginal persons have already been convicted and imprisoned. The objective of this paper is to explore a number of reforms in order to better facilitate rehabilitation, reintegration, and parole for Aboriginal inmates. One is to invest greater resources into culturally sensitive programming that emphasizes spiritual healing for Aboriginal inmates. This is premised on the theme of "spend now, save later" with the idea that increasing the chances for Aboriginal re-integration may represent the better long term investment than simply warehousing large numbers of Aboriginal inmates year after year. Another problem is that many Aboriginal inmates are classified as higher security risks, which results in them being cut off from needed programming. The suggestion here is that criminal history as a static factor for determining security classifications may have little predictive value for the actual security risk posed by Aboriginal inmates, and therefore should be de-emphasized. Correctional Services of Canada should seriously consider developing an Aboriginal-specific classification scale that de-emphasizes criminal history, and emphasizes instead offender participation in culturally appropriate programs and spiritual healing, and behavioural progress while in prison. Risk assessment to re-offend for purposes of granting parole may also represent a form of systemic discrimination since criminal history represents a static factor that encumbers parole for many Aboriginal inmates. Risk assessment should instead emphasize dynamic risk factors by assessing Aboriginal participation in culturally appropriate programming, and attendant behaviourial progress while in prison. The difficult issue of Aboriginal gang activity can perhaps be dealt with through a more flexible system of risk

School of Law, University of Manitoba. An earlier version of this paper was presented at the Canadian Prison-Academic-Community Health and Education Conference on December $4^{\text {th }}$ and $5^{\text {th }} 2008$ at Sty-Wet-Tan, UBC First Nations Longhouse. The author thanks Debra Parkes for her valuable feedback on an earlier version of this paper, as well as the editorial staff of the Yearbook for their assistance. Any remaining errors are solely mine. 
assessment that gauges a willingness to reform and dissociate from the gang lifestyle rather than require Aboriginal inmates to endure nearly permanent penalties for past involvement. Finally, the paper will suggest that it is possible to overcome the political obstacles to implementing these reforms and obtain a political mandate to pursue them after the public is made aware of the benefits they offer.

On continue à infliger des peines d'emprisonnement beaucoup trop sévères aux autochtones. Une grande partie des documents existants examinent des adaptations contemporaines des traditions autochtones en matière de justice qui proposent une forme de justice réparatrice comme solution. Par contre, trop peu de documents examinent la possibilité de rechercher des solutions pendant la phase correctionnelle du système de justice, après que les autochtones ont été reconnus coupables et incarcérés. Cet article examine un certain nombre de réformes en vue de faciliter la réhabilitation et la réintégration des détenus autochtones et leur libération conditionnelle. Nous devons en premier lieu consacrer davantage de ressources aux programmes qui tiennent compte des spécificités culturelles et mettent l'accent sur la guérison spirituelle des détenus autochtones. Cette approche repose sur le principe "dépenser maintenant - épargner plus tard " et sur l'idée selon laquelle accroître les chances de réintégration des autochtones représente peut-être un meilleur investissement à long terme qu'incarcérer ceux-ci en grand nombre année après année. Par ailleurs, le fait qu'un bon nombre d'autochtones soient considérés comme représentant un risque élevé pour la sécurité et ne puissent pour cette raison bénéficier des programmes dont ils ont besoin suscite une autre difficulté. Dans cet article, l'auteur avance que s'appuyer sur les antécédents criminels comme facteur statique pour déterminer les classifications de sécurité a peut-être peu de valeur prédictive en ce qui concerne le risque réel de sécurité posé par les détenus autochtones et, par conséquent, qu'on ne devrait plus leur accorder la priorité. Les Services correctionnels du Canada devraient envisager sérieusement de mettre au point une échelle de classification propre aux autochtones qui n'accorde plus la priorité aux antécédents judiciaires et met plutôt l'accent sur la participation du contrevenant à des programmes culturellement adéquats, sur la guérison spirituelle et sur les progrès comportementaux des autochtones pendant leur incarcération. L'évaluation du risque de récidive avant que ne soit accordée la libération conditionnelle peut également représenter une forme de discrimination systémique puisque les antécédents criminels représentent un facteur statique qui empêche de nombreux autochtones d'obtenir une libération conditionnelle. L'évaluation du risque devrait plutôt mettre l'accent sur les 
facteurs de risque dynamiques en tenant compte de la participation des autochtones à des programmes culturellement adéquats et des progrès comportementaux découlant de cette participation aux programmes pendant l'incarcération. La délicate question des activités de bandes criminelles autochtones pourrait être abordée dans le cadre d'un système plus souple d'évaluation du risque qui tient compte de la volonté de se réformer et de se dissocier du style de vie des gangs au lieu d'exiger que les détenus autochtones subissent des pénalités somme toute permanentes pour leur implication antérieure. Finalement, l'auteur laisse entendre qu'il est possible de surmonter les obstacles politiques à la mise en ouvre de ces réformes et d'obtenir un mandat politique afin de donner suite à ces réformes une fois que le public aura été informé des avantages qu'elles offrent.

\section{INTRODUCTION}

Aboriginal over-incarceration at the correctional and parole phases of the justice system remains a persistent problem in Canada. Even systematically deflated government figures indicate that Aboriginal inmates make up at least $10 \%$ of the federal penitentiary population, with Aboriginal women making up $13 \%$ of the female prison population; yet, Aboriginal people constitute only $2 \%$ of Canada's overall population. ${ }^{1}$ Aboriginal over-representation within the federal prison population has grown from $11 \%$ in $1991 / 92$ to $17 \%$ in $1998 / 99$, and the increase has occurred primarily in the Prairie Provinces. ${ }^{2}$ Estimates as of 2006 show that the incarceration rates for Aboriginal people are 1,024 per 100,000 adults in comparison to 117 per 100,000 adults for non-Aboriginal people. ${ }^{3}$ Aboriginal peoples also continue to be denied parole in disproportionate numbers relative to non-Aboriginal peoples. ${ }^{4}$ They are also over-classified for higher security classifications which can result in being denied needed rehabilitative programming and parole. Howard Sapers completed an independent investigation of Canada's correctional system, concluding that there is systemic discrimination against Aboriginal inmates during both parole and security classification hearings. ${ }^{5}$

This paper will argue that Aboriginal spiritual healing can facilitate the effective rehabilitation of Aboriginal inmates, and help address the problem of Aboriginal over-incarceration. Aboriginal spiritual healing and culturally appropriate programming, when implemented, have proven effective in reforming Aboriginal offenders, improving prison conditions, and preventing recidivism

1 Michael Jackson, “Locking up Natives in Canada” (1988-1989) 23 UBC L Rev 215 at 215-216.

2 Carol LaPrairie, "Aboriginal over-representation in the criminal justice system: A tale of nine cities" (2002) 44:2 Can J Crim 181 at 186-187.

3 Howard Sapers, Annual Report of the Office of the Correctional Investigator 2005-2006 (Ottawa: Minister of Public Safety, 2006) at 11.

4 Andrew Marsh \& James P. Ogloff, "Full Parole and the Aboriginal Experience: Accounting for the Racial Discrepancies in the Release Rates" (2000) 42:4 Can J Crim 469.

$5 \quad$ Supra note 3 at 11 . 
post-release. ${ }^{6}$ Yet, these programmes are too limited in scope and barriers to the full acceptance of Aboriginal spiritual healing methods within prisons remain. This paper identifies and analyzes a number of potential avenues of reform including: the investment of greater resources into culturally sensitive programming for Aboriginal inmates; reconsideration of reliance on criminal history to determine security classifications and parole in favour of a focus on Aboriginal participation in culturally appropriate programming, and attendant behaviourial progress while in prison; and, a different approach to the difficult issue of Aboriginal gang activity through a more flexible system of risk assessment. The measures must be taken together and coupled with a public education campaign to overcome the political obstacles to implementing these reforms and obtain a political mandate to pursue them.

\section{THE THEORY OF ABORIGINAL SPIRITUAL HEALING IN PRISONS}

Aboriginal peoples in Canada were subjected to harmful processes of colonization, which included military conquest, ${ }^{7}$ the acquisition of Aboriginal land bases through treaties, ${ }^{8}$ and policies of assimilation that attempted to force Aboriginal peoples to abandon their own cultures in favour of Euro-Canadian lifestyles by criminalizing cultural activities like the potlatch ${ }^{9}$ and forcing Aboriginal children to attend residential schools. ${ }^{10}$ This is an undeniable fact of Canadian history. Phillip Lane Jr. has catalogued the enduring legacy of colonization and defined how it permeates virtually every aspect of Aboriginal life. "Diseases (such as influenza, small pox, measles, polio, diphtheria, tuberculosis, and later, diabetes, heart disease, and cancer)" ${ }^{, 11}$ can be linked to colonialism. Traditional economies have been destroyed through land and resource expropriation. Identity, spirituality and culture have suffered through "missionization" and various forms of government and private schools, including residential schools. ${ }^{12}$ Indigenous community organizations, governments and cohesion were sidelined through colonialist European power structures including the Indian agent and the council system "which systematically sidelined and

6 See for e.g., Raymond Sioui \& Jacques Thibault, The Relevance of a Cultural Adaptation of the Reintegration Potential Reassessment Scale (RPRS) (Ottawa: Correctional Service of Canada Research Branch, 2001); and Doug Heckbert \& Douglas Turkington, "Turning Points: Factors related to the Successful Reintegration of Aboriginal Offenders" (2002) 14:3 Forum on Correctional Research 55 at 56.

7 Although Canada did not fight wars against its Aboriginal peoples as often as the United States, they did use military subjugation on occasion. A particularly notorious example was the defeat of the Rebellion of 1885 involving Metis and Cree groups. See Olive Patricia Dickason, A Concise History of Canada's First Nations (Don Mills, Ontario: Oxford University Press, 2006) at 234247; and James R. Miller, Skyscrapers Hide the Heavens: a history of Indian-white relations in Canada (Toronto: University of Toronto Press, 2000) at 202-211.

8 For a historical overview of the numbered treaties in the western provinces, see Miller, ibid at 216-224; Dickason, ibid at 173-187.

$9 \quad$ Miller, ibid at 260-263; Dickason, ibid at 184, 224.

10 Miller, ibid at 135-136, 340-341; Dickason, ibid at 227-229

11 Philip Lane, "Mapping the Healing Journey: First Nations Research Project on Healing in Canadian Aboriginal Communities" in Wanda D. McCaslin ed. Justice as Healing: Indigenous Ways (St. Paul, Minnesota: Living Justice Press, 2005) 369 at 370.

12

Ibid. 
disempowered traditional forms of leadership and governance and fractured traditional systems for maintaining community solidarity and cohesion." ${ }^{13}$ Drugs, suicide, depression, alcohol, sexual abuse and dysfunction replaced healthy patterns of life. $^{14}$

James Waldram uses the concept of Post-Traumatic Stress Disorder [PTSD] to explain the role of colonialism and oppressive social conditions in crimes committed by Aboriginal persons who wind up in federal penitentiaries. He notes that certain events such as witnessing death, being kidnapped, being raped, or domestic abuse, can produce acute and prolonged trauma in the persons who experience those events. ${ }^{15}$ These traumas can produce a range of symptoms including "irrational fears, insomnia, nightmares, digestive complaints, depression, anxiety or nervousness, irritability, and outbursts of anger." Those inflicted by PTSD also feel "guilt, shame, fear, and hopelessness," often coupled with selfdestructive and impulsive behaviour. Consequently, victims of PTSD find maintaining meaningful relationships or jobs difficult because of their unpredictable behaviour. $^{16}$

Victims of PTSD can become more given to criminal behaviour. ${ }^{17}$ Paraphrasing the conclusions of psychologist Judith Lewis Herman, Waldman compares the PTSD suffered by Aboriginal peoples with the trauma faced by abused children.

Abused children are survivors. But to survive they must go to extraordinary lengths, such as physically hiding and running away, internalizing the abuse and blaming themselves for being bad, or even cooperating in the abuse to avoid even more severe punishment. Anger, resentment, and hate are engendered. ${ }^{18}$

Waldram interviewed Aboriginal federal inmates in the Saskatchewan Penitentiary, the Regional Psychiatric Centre in Saskatoon, and the Stoney Mountain Penitentiary and Rockwood Institution, both in Winnipeg. ${ }^{19}$ Their interviews revealed various traumatic influences upon their lives that can be traced back to the social conditions they endured. Some participants described racial persecution that often threatened the physical integrity of the inmates, as well as their feeling of safety. ${ }^{20}$ Inmates often experienced a loss of connection to their cultures, which can be traced back to the assimilation policies that criminalized

13 Ibid.

14 Ibid.

15 James Waldram, The Way of the Pipe (Peterborough, Ontario: Broadview Press, 1997) at 44.

16 Ibid.

17 Several studies have suggested that PTSD is a risk factor for subsequent criminal behaviour. See Andrea Friel, Tom White, \& Alistair Hull, "Posttraumatic stress disorder and criminal responsibility" (2008) 19:1 Journal of Forensic Psychiatry \& Psychology 64; Ashley Goff et al, "Does PTSD occur in sentenced prison populations? A systematic literature review" (2007) 17:3 Criminal Behaviour \& Mental Health 152; Patrick S. Calhoun et al. "Severity of Posttraumatic Stress Disorder and Involvement with the Criminal Justice System" (2004) 3:3 Journal of Trauma Practice 1.

18 Waldram, supra note 15 at 45; Waldram is drawing upon Judith Lewis Herman, Trauma and Recovery (New York: Basic Books, 1992) at 113.

19 Ibid at x-xi.

$20 \quad$ Ibid at 56-61. 
Aboriginal cultural practices such as the potlatch and compelled attendance in the residential schools, leading to low self-esteem as Aboriginal persons. ${ }^{21}$ Some inmates experienced physical and emotional abuse in residential schools or in foster homes, while others experienced such abuse by their own parents or relatives, who had been previously scarred in similar ways. ${ }^{22}$ Inmates commonly spoke of extreme poverty, deprivations of the necessities of life and being forced to somehow survive day to day. To escape the harsh realities of their lives, many of the inmates, turned to substance abuse which lowered their self-esteem even further. ${ }^{23}$

Waldram connects these traumas with Aboriginal crime and rehabilitation. Those who commit crimes come from a dysfunctional space. They lived lives defined by an almost complete breakdown in inter-personal relationships and deteriorating self-esteem. As Waldman notes,

Emotionally, the scars are evident. Some men have talked of hate and bitterness. Others expressed profound sadness. They spoke of an inability as adults to love their own families and to trust people. And they demonstrated profound difficulty establishing positive identities for themselves.

He adds: "Trauma operates not only at the individual level but also "at community, societal, and cultural levels." ${ }^{25}$

To be effective, rehabilitation programs must recognize that the trauma experienced by Aboriginal peoples is the product of individual, community, societal and cultural circumstance. Rehabilitation programmes which ignore the multi-dimensional causes of trauma and that focus only on the individual, for example, will likely fail. Waldram thus suggests that Aboriginal Elders adopt the role of both therapeutic healers and spiritual guides for Aboriginal inmates. Because an Elder is also Aboriginal, he or she possesses considerable cultural and spiritual authority, and has often had similar life experiences to those of the inmate, the inmate may be more receptive to his or her teachings. Once an initial rapport is established, the Elder employs various methods of healing. The Elder can place the inmate's pain within the broader contexts of colonialism, racism, social conditions, as well as particular events that have impacted on the inmate's life. This process extends understanding and sympathy to the inmate, and lets the inmate know that he or she remains valued as a person.

The Elder can also instruct the inmate on his or her place in the world, his or her relationships to other people, to the Creator, to ancestral spirits, to the natural world, with the idea of gently discouraging future actions that harm others. The Elder can instruct the inmate on cultural and spiritual values, thereby gently persuading the inmate to reform and become healthier. This also builds an inmate's self-esteem in him or herself as an Aboriginal person. The Elder

\footnotetext{
Ibid at 61-67.

Ibid at 48-56.

Ibid at 67-68.

Ibid at 68 .

Ibid at 68 .

Ibid at 99-109.
} 
maintains a bond of compassion and empathy with the inmate, to assure the inmate that the elder has the inmate's best interests in mind. ${ }^{27}$ Finally, the Elder can engage inmates with the healing process through cultural ceremonies such as talking circles, pipe ceremonies, and sweat lodges. ${ }^{28}$

The federal government has legislative allowances for these ideas and programs. The next section of this paper describes corrections programmes that already include Aboriginal spiritual and community elements. It explains that these elements are successful but insufficient.

\section{ABORIGINAL PEOPLES IN CORRECTIONS AND PAROLE}

Federal penitentiaries are for offenders sentenced to a term of imprisonment exceeding two years while Provincial jails are for those serving two years or less. ${ }^{29}$ In both types of institutions, correctional programs are often available that emphasize rehabilitation and gradual re-integration of offenders into the community after release. The types of services available to inmates include educational upgrading classes, anger management counseling, substance abuse treatment, and life skills training. ${ }^{30}$ The programs are also both less available and less accessed within provincial institutions given the much shorter incarceration terms being served within them. ${ }^{31}$ This paper will focus on the federal prison system as an opportunity to address Aboriginal over-incarceration, since it provides a real opportunity to engage in long-term programming to address Aboriginal criminality as opposed to the routinely transitory nature of provincial jail terms.

Section 80 of the Corrections and Conditional Release Act [CCRA] mandates that the Canadian Correctional Service [CSC] shall "provide programs designed particularly to address the needs of aboriginal offenders." ${ }^{32}$ One reason for this provision is to provide services such as life skills training or substance abuse treatment, including the inculcation of Aboriginal cultural values as part of the treatment or training and to facilitate inmate participation in cultural activities, such as training in traditional spiritual practices or sweat lodge ceremonies. ${ }^{33}$ These services are often delivered by Elders or other members of Aboriginal communities with similar cultural authority. ${ }^{34}$ The rationale behind these

\footnotetext{
27 Ibid at 71-75.

28 Ibid at 85-96; For other works with similar themes, see Emily R. Brault, Sweating in the Joint: Personal and Cultural Renewal and Healing Through Sweat Lodge Practice by Native Americans in Prison (Doctoral Dissertation, Vanderbilt University Department of Religion, 2005) [unpublished]; Lee Irwin, "Walking the Line: Pipe and Sweat Ceremonies in Prison" (2006) 9:3 Nova Religion: The Journal of Alternative and Emergent Religions 39. 
approaches is that the CSC identifies the loss of cultural identity as the underlying cause of Aboriginal criminality.

Another objective of correctional programming is to prepare inmates for parole. $^{36}$ Canadian correctional legislation contains directives to consider the circumstances of Aboriginal offenders and alternatives that can lessen terms of incarceration. Section 102 of the CCRA sets out the criteria for granting parole:

The Board or a provincial parole board may grant parole to an offender if, in its opinion,

a. the offender will not, by reoffending, present an undue risk to society before the expiration according to law of the sentence the offender is serving; and

b. the release of the offender will contribute to the protection of society by facilitating the reintegration of the offender into society as a law-abiding citizen. ${ }^{37}$

The Parole Board's Policy Manual provides an additional gloss to this provision by mandating consideration of certain factors as follows:

Any systemic or background factors that may have contributed to the offender's involvement in the Criminal Justice System, such as, the effects of substance abuse in the community, racism, family or community breakdown, unemployment, income, and a lack of education and employment opportunities, dislocation from his/her community, community fragmentation, dysfunctional adoption and foster care, and residential school experience.

Sections 84 and 84.1 allow Aboriginal convicts to apply for parole and release, typically under supervised conditions, into an Aboriginal community with a view towards re-integration with that community. Notice to the Aboriginal community is required, which provides the Aboriginal community an opportunity to propose a plan of supervision and re-integration. ${ }^{39}$

The parole hearing process also allows the presence of Aboriginal Elders to provide background information that will assist the Board in reaching appropriate decisions. The Policy Manual describes Elders as a source of advice and support. The Manual reads:

35 Carole LaPrairie, Examining Aboriginal Corrections in Canada (Ottawa: Aboriginal Corrections, Ministry of the Solicitor General, 1996) at 83.

National Parole Board of Canada, Your Guide to Parole (Ottawa: Correctional Service of Canada, 2010).

Corrections and Conditional Release Act, supra note 32, s. 102.

38 National Parole Board, Policy Manual, vol. 1, no. 13 (Ottawa: National Parole Board, 2008) at 2.1 -2 .

39 Corrections and Conditional Release Act, supra note 32, ss. 84 \& 84.1. 
The role of the Elder/Advisor is to provide Board members with information about the specific cultures and traditions of the Aboriginal population the offender is affiliated with, and/or Aboriginal cultures, experiences, and traditions in general.

The Elder/Advisor may be an active participant in the hearing and may ask about the offender's understanding of Aboriginal traditions and spirituality, progress towards healing and rehabilitation, and readiness of the community to receive the offender if return to the community is part of the release plan. The Elder/Advisor may speak with the offender in an Aboriginal language to gain a better understanding of the offender, and to assist the Board members with gaining further information helpful to achieving a quality decision. The Elder/Advisor will summarise such an exchange for the Board members and others at the hearing before the decision is made.

The Elder/Advisor may also offer wisdom and guidance to the offender and may advise the Board members during the deliberation stage of the hearing to provide insights and comments with respect to cultural and spiritual concerns.

A similar accommodation allows parole hearings to be heard in Aboriginal communities; also known as "releasing circles," they allow Aboriginal communities to have input into the determinations.

When the National Parole Board grants parole, the delivery of correctional programming often continues thereafter. The early stages of parole are often spent in a residential correctional facility, a halfway house. A halfway house, while not a prison, requires the offender to reside there and not be absent save under specific exceptions (e.g. supervised absences or employment). ${ }^{42}$ It is a transitory phase in an offender's parole that is neither full incarceration, nor full freedom in the community but assists in the offender's gradual re-integration into the community. ${ }^{43}$ Many of the services available in federal penitentiaries are often available in halfway houses as well. ${ }^{44}$ A number of halfway houses are designed specifically to provide culturally sensitive services for the re-integration of Aboriginal offenders. These include but are not limited to the Forensic Behavioural Management Clinic for sex offenders in Winnipeg, the Stan Daniels Centre in Edmonton, Waseskun House in Montreal, the AIMS House in Vancouver, ${ }^{45}$ and the Elbow Lake Institution run by the Chehalis First Nation in

\footnotetext{
$40 \quad$ Ibid at 9.2.1 - 1 .

41 National Parole Board, "Fact Sheet: Hearings for Aboriginal Offenders", online: National Parole Board < http://www.pbc-clcc.gc.ca/infocntr/factsh/hearing-eng.shtml>.

42 John Howard Society of Alberta, Halfway House (Edmonton: John Howard Society of Alberta, 2001) at $1-2$.

43 Ibid at 2-4.

44 Ibid at $1-2$

45 LaPrairie, supra note 35 at 80-83.
} 
British Columbia. $^{46}$ In 2003, the Beardy's and Okemasis First Nation in Saskatchewan began operation of a 40 bed minimum security institution called the Willow Cree Healing Lodge. In addition to core programs that address educational and living skill needs, the facility also provides healing circles and programs designed to raise cultural and spiritual awareness. ${ }^{47}$ It is easy to idealize Aboriginal spiritual healing as an alternative route to rehabilitation and parole but whether it works in practice is an important consideration.

\section{DOES ABORIGINAL SPIRITUAL HEALING WORK IN CORRECTIONS PROGRAMMING?}

When culturally appropriate programming is effectively implemented and provided to Aboriginal inmates, the evidence often bears out that it produces positive results. Studies based on interviews with Aboriginal inmates have confirmed that participation in Aboriginal spirituality can contribute to the healing of the inmates, to increasing self-esteem, and making positive changes in lifestyle that assist release and re-integration. ${ }^{48}$

Sometimes success can also be found in improvements in the prison environment itself. For example, the Ma Mawi program, based in the Stoney Mountain Institution in Manitoba, is a program designed for Aboriginal inmates who have been convicted for domestic violence offences. ${ }^{49}$ It approaches the problem through a combination of healing and spiritual ceremonies, and educational components that are designed to help inmates understand and control their violence, develop healthier relationships, and develop parenting skills. Many of the Aboriginal inmates who were interviewed indicated that the program offered a positive experience since it provided their first exposure to their traditional cultures, and helped them understand and control their violence. Correctional staff also noted positive changes, including reduced aggression in the inmates, and improved relationships between staff and inmates. ${ }^{52}$

Aside from qualitative research, a consultation study by Raymond Sioui and Jacques Thibault provides statistical proof that approaches to rehabilitation based on Aboriginal cultures and spirituality are effective. ${ }^{53}$ The recidivism rate for Aboriginal offenders who had participated in cultural activities was $3.6 \%$ in

46 "Commissioner of Corrections signs Memorandum of Understanding with Chehalis First Nation" C.C.N. First Nation (May 2, 2001).

47 Cheryl Petten, "New Healing Lodge Opens for Offenders" (16 August 2003) 7:11 Saskatchewan Sage 1.

48 For a study that involved interviews with inmates in a minimum security institution designed specifically for Aboriginal inmates, see Connie Braun, Colonization, Destruction, and Renewal: Stories from Aboriginal Men at the Pe' Sakastew Centre (Master's Thesis, Department of Sociology, University of Saskatchewan, 1998) [unpublished]; Waldram, supra note 15 at 129150; Nicole Crutcher \& Shelley Trevethan, "An Examination of Healing Lodges for Aboriginal Offenders in Canada" (2002) 14:3 Forum on Corrections Research 52.

Evelyn Zellerer, "Culturally Competent Programs: The First Family Violence Program for Aboriginal Men in Prison" (2003) 83:2 The Prison Journal 171.

Ibid at 180.

Ibid at 182-183.

Ibid at 183.

Sioui \& Thibault, supra note 6. 
comparison to $32.5 \%$ for those who had not. ${ }^{54}$ The recidivism rate was $14.4 \%$ for those who had participated in spiritual activities (e.g. sweat lodge ceremony) in comparison to $24.2 \%$ for those who had not. ${ }^{55}$ The recidivism rate was $12.9 \%$ for those inmates who had contacts or meetings with an Aboriginal Elder in comparison to $26.8 \%$ who had not. ${ }^{56}$ A survey report by Doug Heckbert and Douglas Turklington provides additional confirmation. They interviewed 56 male and 12 female Aboriginal ex-offenders who had stayed out of trouble with the law for at least two years following their release. While other factors such as family support and steady employment were important in keeping them out of trouble, a large percentage of the respondents indicated that participation in spiritual ceremonies (71\%) and cultural activities (68\%) were also important in helping them stay out of trouble. ${ }^{57}$

Other indicators also point to the efficacy of Aboriginal spirituality and cultural accommodations. For example, success can also be achieved in a halfway house setting. Marianne O. Neilsen noted that the Stan Daniels centre enjoyed a recidivism rate of $3.5 \%$ from the years 1988 to 2001, and suggested that the Aboriginal healing lodge as implemented in Canada could provide a model worth implementing in dealing with American Indian over-incarceration. ${ }^{58}$ Sometimes success can be gauged by a greater willingness to undergo and complete programs when they are culturally appropriate in comparison to standard programming. One consultation study found that Aboriginal sexual offenders completed treatment programs less often than those of non-Aboriginal offenders prior to the introduction of culturally sensitive programming. ${ }^{59}$ The differences in completion rates disappeared after culturally sensitive treatment programs were available. ${ }^{60}$

Despite these legislative and programming accommodations, considerable problems remain with Aboriginal inmates being denied access to meaningful programming and opportunities for parole. In 1996/1997, it was found that Aboriginal offenders were granted parole at a rate of $34 \%$ compared to $41 \%$ for non-Aboriginal offenders. ${ }^{61}$ In 1998 it was found that Aboriginal inmates waived their right to a parole hearing at a rate of $49 \%$ in comparison to $30 \%$ for nonAboriginal offenders. ${ }^{62}$ Explanations for this discrepancy include Aboriginal

\footnotetext{
$54 \quad$ Ibid at 43.

55 Ibid at 42.

56 Ibid at 44.

57 Heckbert \& Turkington, supra note 6 at 56.

58 Marianne O. Neilsen, "Canadian Aboriginal Healing Lodges: A Model for the United States?" (2003) 83:1 The Prison Journal 66. The recidivism statistic is provided at 81.

59 L.A. Ellerby \& P. MacPherson, Exploring the Profiles of Aboriginal Sex Offenders: Contrasting Aboriginal and Non-Aboriginal Sexual Offenders to Determine Unique Client Characteristics and Potential Implications for Sex Offender Assessment and Treatment Strategies, Research Report R122 (Ottawa: Correctional Service of Canada, 2002) at 50.

$60 \quad$ Ibid at 51.

61 Andrew Marsh \& James P. Ogloff, supra note 4 at 472.

62 Solicitor General of Canada, Canadian Correctional Release Assessment, 5 Year Review: Aboriginal Offenders (Ottawa: Minister of Supply and Services, 1998).
} 
inmates lack of knowledge of the parole process ${ }^{63}$ and Aboriginal inmates mistrust of correctional staff causing a lack of hope in the process. ${ }^{64}$ Howard Sapers adds:

The Correctional Service's own statistics confirm that correctional outcomes for Aboriginal offenders are not improving in many areas that the Correctional Service can positively influence. The Final Report: Task Force on Aboriginal Peoples in Federal Corrections in 1988 found that Aboriginal offenders were less likely to be granted temporary absences and parole, were granted parole later in their sentence, were more likely to have their parole suspended or revoked and were more likely to be classified at a higher security level. Unfortunately, this is as true today as it was nearly 20 years ago.

It is apparent that despite some accommodations of Aboriginal approaches to rehabilitation, and documented instances of success, not much headway has been made in addressing the problem of Aboriginal over-incarceration, at least within the federal system. The remainder of this article will explore lingering obstacles as well as potential avenues to overcome them.

\section{RE-ALLOCATION OF RESOURCES}

Although the federal government has enacted correctional legislation designed to accommodate the needs of Aboriginal inmates, and has implemented some culturally appropriate programs for Aboriginal offenders, the resource allocations do not reflect a serious effort to address the problem of Aboriginal overincarceration. Carol LaPrairie notes that the availability of culturally sensitive rehabilitative programs to Aboriginal inmates varies greatly from institution to institution, with the result that many Aboriginal inmates do not have access to such programming at all. ${ }^{66}$ Sioui and Thibault note that despite statistical successes, participation in culturally sensitive programs was very low. The number of participants in certain types of programs ranges from 140 to 195 out of the 4,819 Aboriginal offenders who had been released between January 1996 and June $2000{ }^{67}$ They ascribe this low level of participation to very little access to culturally sensitive programming. ${ }^{68}$ Howard Sapers indicated before a Senate Standing Committee on Legal and Constitutional Affairs that the Canadian Correctional Service had an annual budget of $\$ 1.8$ billion, and yet allocated only $\$ 27$ million of

63 J.C. Johnston, Northern Aboriginal Offenders in Custody: a Profile (Ottawa: Correctional Service of Canada, 1994).

64 J.C. Johnston, Aboriginal Offender Survey: Case Files and Interview Sample (Ottawa: Correctional Service of Canada, 1997).

65 Supra note 3 at 11. Sapers is referring to Task Force on Aboriginal Peoples in Federal Corrections: Final Report (Ottawa: Ministry of the Solicitor General, 1988) at 27-31 as a basis for past comparison.

66 Supra note 35 at $84-85$.

$67 \quad$ Supra note 6 at 17.

68 Raymond Sioui \& Jacques Thibault, "Examining Reintegration Potential for Aboriginal Offenders" (2002) 14:3 Forum on Corrections Research 49 at 51. 
that for the delivery of core rehabilitative programming (e.g. substance abuse counseling, life skills training, educations programming, etc.). He then indicates that in light of this fact, it was hardly surprising that many Aboriginal inmates had no access to culturally specific programs that could help them progress towards release. $^{69}$ Sapers' evidence shows that the low amount invested into rehabilitative programming, both for Aboriginal and non-Aboriginal inmates alike, results in culturally specific programs being available only at a limited number of federal institutions and only to a minority of Aboriginal inmates in the system.

Section 81 of the CCRA allows the Minister of Public Safety to enter into an agreement with an Aboriginal community so that the Aboriginal community can provide correctional services to Aboriginal offenders. This is the legislative basis for Aboriginal-specific halfway houses. ${ }^{70}$ Another problem is that there are not enough Aborignial-specific halfway houses to meet the need. The Correctional Service of Canada notes that there are currently 24 such halfway houses across the country. ${ }^{71}$ For example, there is only one halfway house with culturally specific programming for Aboriginal inmates in Saskatoon, an urban centre with a significant Aboriginal population. ${ }^{72}$ Crutcher and Trevethan also note that the Aboriginal-specific halfway houses that are in operation are plagued by a number of problems, including lack of funding, lack of resources, lack of adequately trained staff, high staff turnover, and weaker rehabilitative programming offered to residents because of the lack of funding. ${ }^{73}$

Even after full parole is granted to an Aboriginal inmate, there may be concerns about the lack of available services that can assist Aboriginal parolees with effective re-integration. A study by Jason Brown found that Aboriginal parolees often faced a lack of adequate housing, or racist discrimination from prospective landlords. ${ }^{74}$ Vulnerability to residential instability increases a parolee's risk of re-offending. ${ }^{75}$ The study stressed the need for increased community supports so that Aboriginal parolees can find adequate housing and can stay out of trouble.

\section{COSTS OF INCARCERATION VERSUS INVESTING MORE INTO PROGRAMMING}

The Canadian government should seriously consider whether to invest greater budgetary allocations to increase the culturally appropriate rehabilitative

\footnotetext{
69 "Speaking Notes for Mr. Howard Sapers, Correctional Investigator of Canada: Appearance before the Senate Standing Committee on Legal and Constitutional Affairs, (Thursday, February 14, 2008, 12:00-13:30)" online: Office of the Correctional Investigator <http://www.oci-bec.gc.ca/ comm/sp-all/sp-all20080214-eng.aspx.>.

70 Corrections and Conditional Release Act, supra note 32, s. 81.

71 "Facts and Figures: Aboriginal Community Development in Corrections", online: Correctional Service of Canada < http://www.csc-scc.gc.ca/text/prgrm/abinit/know/7-eng.shtml.>

72 Issues in Urban Aboriginal Corrections: Report on a Focus Group and an Overview of the Literature and Experience (Ottawa: Solicitor General, 1998) at 23.

$73 \quad$ Supra note 48 at 56.

74 Jason D. Brown et al., "Housing for Aboriginal Ex-Offenders in the Urban Core" (2008) 7 Qualitative Social Work 238 at 244-245.

$75 \quad$ Ibid at 247

76 Ibid at 249-250.
} 
programming available to Aboriginal inmates, within federal institutions, within halfway houses, and for community resources post-release, if for no other reason than one of long term expediency. Keeping Aboriginal inmates warehoused in the federal prison system is far more expensive in the long term than funding effective rehabilitation programmes. In 2006, the federal government incurred annual costs of $\$ 110,223$ for each male inmate and $\$ 150,867$ for each female inmate confined in a maximum security institution. ${ }^{77}$ The annual cost per inmate in a medium and minimum security institution is $\$ 70,000 .^{78}$ By contrast, research has frequently asserted that halfway houses, coupled with meaningful programming and treatment, are more cost effective relative to continued incarceration. These costs become even lower once full parole is attained. ${ }^{79}$ In 2001 , it cost $\$ 30,000$ to maintain an offender in a halfway house compared to $\$ 60,000$ for a male offender in a federal penitentiary and $\$ 114,000$ for a female offender in a federal penitentiary. ${ }^{80}$ In the 2001/2002 fiscal year, $71 \%$ of expenditures by the Correctional Service of Canada were on custodial services, while $13 \%$ were on community supervision services. ${ }^{81}$ Inmates serving time in federal institutions or provincial jails accounted for only $15 \%$ of the convicts covered by the budget. The Prison Justice Day Committee indicates that those percentages were almost unchanged during the 2004/2005 fiscal year, with the Correctional Service using $71 \%$ of its budget to keep 31,500 inmates in custody while $14 \%$ was spent supervising 120,500 persons in the community. ${ }^{83}$ The numbers indicate the high cost of incarceration compared to community supervision and support mean that more resources should be poured into culturally appropriate programming to save more in the long run by preparing Aboriginal inmates sooner and faster for halfway house residency and ultimately offloading once full parole and reintegration is achieved. "Spend now, save later" is the idea. But, resource allocation is not the only problem that contributes to the over-representation of Aboriginal peoples in custody. The security classification system also poses a problem.

\section{SECURITY CLASSIFICATION AND PAROLE}

Studies repeatedly demonstrate that Aboriginal offenders are placed in stricter security classifications in disproportionate numbers compared to non-Aboriginal offenders. The Task Force of Federally Sentenced Women in 1990 found that Aboriginal women were much more likely to receive higher security classification

\footnotetext{
77 Ira Basen, "Doing the Crime and Doing the Time" (January 5, 2006) online: Canadian

79 Vincent D. Basile, "Getting Serious About Corrections" (2005) 69:2 Federal Probation 29; Bruce L. Benson, To Serve and Protect: Privatization and Community Control in Criminal Justice (New York: New York University Press, 1998); E. Latessa \& H.E. Allen, "Halfway houses and parole: A national assessment" (1982) 10 Journal of Criminal Justice 153.

83 Prison Justice Day Committee, Behind Bars in Canada: the Costs of Incarceration (Vancouver: Prison Justice Day Committee, 2008).
} 
than non-Aboriginal women. ${ }^{84}$ The Native Women's Association of Canada estimated that as of 2003, Aboriginal women comprised at least $50 \%$ of incarcerated federal women classified as maximum security. ${ }^{85}$ A study by Andrew Welsh and James Ogloff in 2000 found that Aboriginal inmates were classified as maximum security or medium security at rates of $27.7 \%$ and $34.7 \%$ respectively, in comparison to rates of $20.3 \%$ and $24.1 \%$ for non-Aboriginal offenders. ${ }^{86}$ The security classification system can prejudice an inmate's ability to pursue reintegration through correctional programming and parole. The Canadian Human Rights Commission describes the consequences of irrational maximum security classification on female inmates. The Commission notes,

Among the hardships imposed by this are the fact that maximum security inmates, unlike their minimum and medium security counterparts, are not eligible to participate in work-release programs, community release programs or other supportive programming designed to enhance their chances of reintegration. In fact, half of all maximum security women are now being released directly from maximum security incarceration into the community after serving two-thirds of their sentence, without the benefit of preparatory programming. ${ }^{87}$

Those who are arguably most in need of preparatory programming are systematically denied them.

As Tamara Walsh emphasizes, keeping long-term inmates in maximum security and then releasing them is detrimental because the inmates are released without having had adequate correctional programming, with a lack of resources and supports to facilitate rehabilitation. ${ }^{88}$ Release under such circumstances is also potentially threatening to public safety.

Initial determination of security classification upon arrival in a federal penitentiary is made using the Custody Ratings Scale. Under this scale, a score of 133.5 or higher on the Security Risk component of the Custody Ratings Scale qualifies an inmate for maximum security. ${ }^{90}$ It is here where prior history can operate as a static factor to the detriment of many Aboriginal inmates. Negative points for the initial sentence are 20 for a five to nine year sentence, 45 points for 10 to 24 years, and 65 points for 25 years or more.. Being younger is also

84 Task Force of Federally Sentenced Women, Creating Choices (Ottawa: Correctional Service of Canada, 1990) at 112.

85 Elizabeth Fry Society, Discrimination Against Aboriginal Women Rampant in Federal Prisons Claims the Native Women's Association of Canada (Ottawa: Elizabeth Fry Society, 2003).

86 Andrew Welsh \& James R.P. Ogloff, "Full Parole and the Aboriginal Experience: Accounting for the Racial Discrepancies in Release Rates” (2000) 42:4 Can J Crim 469 at 479.

87 Canadian Human Rights Commission, Protecting Their Rights: A Systemic Review of Human Rights in Correctional Services for Federally Sentenced Women online: <http://www.chrcccdp.ca/ legislation_policies/consultation_report-en.asp.>. Tamara Walsh, "Is Corrections Correcting? An Examination of Prisoner Rehabilitation Policy and Practice in Queensland" (2006) 39:1 Austl Crim \& NZJ 109 at 116-117.

89 Ibid at 120-122.

90 Brian A. Grant \& Frank Luciani, Security Classification Using the Custody Rating Scale (Ottawa: Research Branch, Correctional Service of Canada, 1998). 
detrimental, with penalties for age at time of offence ranging from three points for 34 years of age, to 30 points for being 24 years of age or younger. Twelve points are assigned for minor or moderate offences, while 36 points are assigned for serious or major offences. Penalties are also assessed for prior convictions, with three points for one prior conviction, six points for two to four prior convictions, nine points for five to nine prior convictions, 12 points for 10 to 14 prior convictions, and 15 points for 15 or more prior convictions. ${ }^{91}$

After the initial determination, a CSC Commissioner's Directive requires that an offender's security classification be periodically re-determined with the assistance of a Security Reclassification Scale. ${ }^{92}$ Reclassification is to be considered at least once a year, or when there is cause to believe that an offender should no longer be in minimum security, or every two years for offenders serving a life sentence for murder or a terrorist offence. ${ }^{93}$ The factors that are considered in whether to move an offender from one security classification to another are as follows:

a. The seriousness of the offence committed by the offender;

b. Any outstanding charges against the offender;

c. The offender's performance and behaviour while under sentence;

d. The offender's social, criminal and, where available, young offender history;

e. Any physical or mental illness or disorder suffered by the offender;

f. The offender's potential for violent behaviour;

g. The offender's continued involvement in criminal activities. $^{94}$

Note that the seriousness of the offence for which the offender has been imprisoned, and past criminal history, including youth offences, remains relevant to determining security reclassification. Aboriginal inmates are placed at a disadvantage during security reclassification determinations because as studies have shown that in the aggregate they have worse criminal histories than nonAboriginal inmates. ${ }^{95}$ One study shows that at least $80 \%$ of Aboriginal federal inmates had previously served terms in provincial jails compared to approximately $70 \%$ for non-Aboriginal inmates. Inuit and First Nations federal inmates were more likely to have served a previous adult community supervision sentence, at

\footnotetext{
Ibid at 19-21.

92 Correctional Service of Canada, Commissioner's Directive 710-6 - Review of Offender Security

95 A.M. Holsinger, C.T. Lowenkamp, \& E.J. Lotessa, "Ethnicity, Gender, and the Level of Service Inventory - Revise" (2003) 31:4 J Crim Just 309; Welsh \& Ogloff, supra note 86; R.G. Hann \& W.G. Harman, Predicting Release Risk for Aboriginal Penitentiary Inmates (Ottawa: Solicitor General, 1993).

John-Patrick Moore, First Nations, Metis, Inuit and Non-Aboriginal Offenders: A Comparative Profile (Ottawa: Correctional Service of Canada - Research Branch, 2003) at 44.
}

96 
rates of $87 \%$ and $79 \%$ respectively, in comparison to $72 \%$ for non-Aboriginal inmates. ${ }^{97}$ First Nations and Metis also have greater involvement with the youth justice system. First Nations offenders served terms in closed custody at a rate of $40 \%$, terms in open custody at a rate of $39.5 \%$, and underwent community youth supervision at a rate of $53 \%{ }^{98}$ For Metis offenders, the rates were $45.9 \%, 42.3 \%$, and $57.3 \%$. $^{99}$ For Non-Aboriginal offenders, the rates were $27.5 \%, 24.9 \%$, and $34 \%{ }^{100}$ First Nations inmates are more likely to be convicted for homicide offences, at a rate of $28 \%$, in comparison to $24 \%$ for non-Aboriginal inmates. ${ }^{101}$ Inuit $(39 \%)$, First Nations $(39 \%)$, and Metis $(33 \%)$ federal inmates were more likely to have committed a major assault crime than non-Aboriginal inmates $(26 \%){ }^{102}$ Inuit offenders are far more likely to be convicted of sexual assault, at a rate of $62 \%$, than Metis inmates at $16 \%$, First Nation inmates at $22 \%$, and nonAboriginal inmates at $17 \%$.

The crime statistics have repercussions for initial security classification where Aboriginal inmates were recommended for maximum-security placement at a rate of $21 \%$, in comparison to non-Aboriginal inmates at $15 \% .^{104}$ The Commissioner's Directive on Security Classification does stress that CSC staff are to make a genuine effort to consider factors relevant to Aboriginal offenders, such as history of family dislocation, lack of employment opportunities, lack of education, history of substance abuse, history of system or direct discrimination, and history of participation in Aboriginal ceremonies and cultural activities. ${ }^{105}$ It is a fair question to ask whether this part of the Directive results or will result in any tangible benefits for Aboriginal inmates while static factors involving prior history remain a substantial component of security classification determinations. Aboriginal offenders continue to be placed more often in higher security classifications, and it is hard to ignore that the seriousness of the offence for which the inmate has been incarcerated, and previous criminal history, youth history included, will represent enduring penalties for Aboriginal offenders, even during reclassification determinations. The security classification scheme therefore, as applied to Aboriginal inmates, may represent a form of systemic discrimination.

Significantly, a study by Cheryl Webster and Anthony Doob found that criminal history has no predictive value whatsoever when it comes to the involvement of Aboriginal women with institutional incidences. ${ }^{106}$ Aboriginal women in maximum security institutions were involved in institutional incidents at a percentage $(28.6 \%)$ comparable to female inmates in medium and minimum

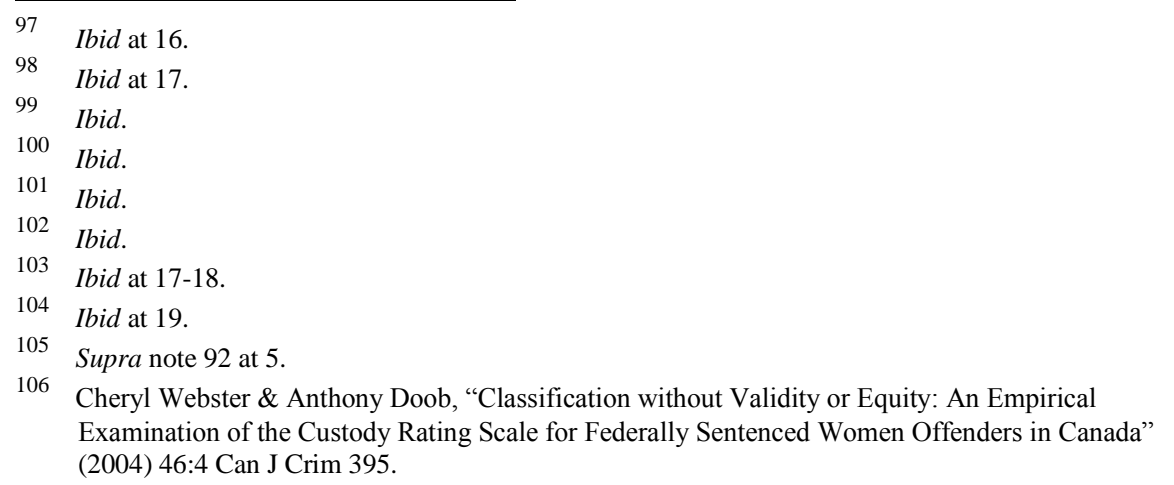


security institutions $(26.8 \%){ }^{107}$ The study also found that correlation between the Security Risk Score (based on previous criminal history) and involvements in institutional incidences were practically of zero strength, 0.01 for violent incidences and 0.05 for non-violent incidences. ${ }^{108}$ Aboriginal women are thus more routinely placed into tighter security settings despite the fact that their criminal history has no predictive value for whether they are genuinely a risk to other inmates or staff. ${ }^{10}$

The security classification system has been criticized for not giving adequate attention to the social context that brings many Aboriginal people into the prison system. Jena McGill for example notes that Aboriginal women are far more likely to be subject to poverty, discrimination, and violent victimization. ${ }^{110}$ She then adds:

The "one-size-fits-all" classification system employed by the CSC denies the complexity of Aboriginal women's lives by attempting to dissect them into discrete categories for the purposes of "needs classification", and problematically rejects any kind of contextual consideration of the impact that the systemic marginalization experienced by Aboriginal women in Canadian society is likely to have on their social histories. ${ }^{111}$

Patricia Monture-Angus adds with reference to both Aboriginal men and women offenders:

These risk scales are all individualized instruments. This must be seen as a significant and central problem for applying these instruments to Aboriginal people (male or female). This individualizing of risk absolutely fails to take into account the impact of colonial oppression on the lives of Aboriginal men and women. Equally, colonial oppression has not only had a devastating impact on individuals but concurrently on our communities and nations. This impact cannot be artificially pulled apart because the impact on the individual and the impact on the community are interconnected. ${ }^{112}$

There are however alternative approaches to institutional security that aspire to remedy the system discrimination latent in standard risk predictor instruments. One approach is to develop a classification scale specific to Aboriginal offenders that addresses the concerns expressed by McGill, Monture-Angus, and others. The scale would have little or even no emphasis on static factors such as criminal

107

108

109

110

111

112

Ibid at 400 .

Ibid at 402 .

Ibid at 401-402.

Jena McGill, “An Institutional Suicide Machine: Discrimination against Federally Sentenced Aboriginal Women in Canada" (2008) 2:1 Race \& Ethnicity 89 at 98.

Ibid at 99.

Patricia-Monture Angus, “Aboriginal Women and Correctional Practice: Reflections on the Task Force on Federally Sentenced Women" in Kelly Hannah-Moffat \& Margaret Shaw (eds.) An Ideal Prison? Critical Essays on Women's Imprisonment in Canada (Halifax, Nova Scotia: Fernwood Publishing, 2000) 52 at 56. 
history, and would instead place primary emphasis on the offenders' correctional needs and his or her progress with good behaviour while incarcerated.

There is reason to believe that an alternative scale may indeed be workable. The Security Reclassification Scale for Women [SRSW] was developed as a gender-specific method of security classification for female offenders ${ }^{113}$ with nine items considered:

1. Correctional plan; program motivation.

2. Maintains regular positive family contact.

3. Number of convictions for serious disciplinary offences during the review period.

4. Number of recorded incidents during the review period.

5. History of escape or unlawfully at large from work release, temporary absence or community supervision.

6. Pay level during the review period.

7. Number of times the offender was placed in involuntary segregation for being a danger to others or the institution during the review period.

8. Total number of escorted temporary absences [ETAs] during the review period.

9. Custody Rating Scale incident history. ${ }^{114}$

Note the de-emphasis on static factors involving the offence, or previous criminal history, and a greater emphasis on progress with behaviour during the review period. Early field tests involving 580 files have found that the scale is reliably predictive of actual security risk. ${ }^{115}$ Statistically significant correlations were found between SRSW scores and involvements in major and minor institutional incidences, at $r .=33$ and $r .=32$ respectively. ${ }^{116}$ In an Area Under the Curve [AUC] statistical calculation, a score of 1.0 means perfect predictive power, while a score of 0.50 or less means no predictive power. The SRSW had an AUC score of 0.73 . $^{117}$

Given that there is evidence that Aboriginal spiritual healing can improve offender behaviour, and improve prison conditions generally, is there any legitimate reason why the Canadian correctional system should not develop an Aboriginal-specific classification scale? The scale can have little or no emphasis on static factors tied to previous criminal history. The scale instead would place emphasis on escape history, history of successful escorted temporary absences, and progress with culturally appropriate programming, progress with participation in cultural and spiritual activities, and behavioural progress while in prison. If Aboriginal spiritual healing continues to demonstrate its power to address the systemic factors behind Aboriginal criminality, to lead Aboriginal inmates towards

\footnotetext{
113 Kelley Blanchette \& Kelly Taylor, "Development and Validation of a Security Reclassification 
positive reform, and to improve prison conditions overall, this should then constitute the primary emphasis in an Aboriginal-specific classification scale.

Another approach to security classification lies in finding alternatives to address institutional misconduct that do not implicate security classifications. Neilsen notes that the Stan Daniels Centre contains strict rules that enforce curfew, cleanliness, conduct during supervised visits, and prohibit drug use, ${ }^{118}$ but adds:

These more bureaucratic rules are counterbalanced by policies based in Aboriginal practices so that, for example, rule breaking and interresident conflict are dealt with by a "sharing circle," a form of case conferencing, rather than a disciplinary hearing. Instead of receiving a fine, being put in segregation, or being sent back to the correctional institution, they may have to make an apology in front of a general meeting of the residents or make restitution by cutting wood for a sweat or by creating a piece of artwork dealing with forgiveness.

The idea is that many instances of institutional misconduct can be addressed through informal measures. It would only be in the clearest instances, when an inmate continues to engage in misconduct despite any previous efforts at correction, that a security reclassification may be warranted. Another avenue of reform involves risk assessment for purposes of parole.

\section{RISK ASSESSMENT AND PAROLE}

When the National Parole Board makes a decision whether to grant an offender's application for parole, the Board must assess whether the application is meritorious such that public safety will not be endangered. ${ }^{120}$ There is no doubt that the Board faces a difficult task. When a released offender goes on to re-offend, especially when it is a homicide offence, public fury naturally ensues. Examples include Eric Fish, who murdered two people in 2004 within six weeks after walking out of his half-way house, ${ }^{121}$ and Daniel Jonathan Courchene, a known member of the Manitoba Warriors gang who was kept on parole despite several substance abuse related parole violations. Courchene went on to attempt the murders of a police officer and a homeowner during a home invasion while on parole. ${ }^{122}$ However, as of 2002 , homicide while on release amounted to only $0.3 \%$ of parolees. ${ }^{123}$ In other words, the Parole Board very rarely exposes the public to mortal peril. The pertinent question for purposes of this study is how to facilitate

\footnotetext{
Supra note 58 at 75.

Ibid at 76.

120 Correctional Service of Canada, Protecting Society Through Community Corrections (Ottawa: Correctional Service of Canada, 1999).

121 "Man who fled Vernon halfway house charged in $2^{\text {nd }}$ slaying" CBC News (28 February 2007) online: Canadian Broadcasting Corporation < http://www.cbc.ca/canada/britishcolumbia /story/2007/02/28/fish-murder.html >.

122 "Shot Manitoba RCMP officer seeks to sue parole board" CTV News (12 March 2002) online: CTV News <http://www.ctv.ca/CTVNews/CTVNewsAt11/20020312/ctvnews850771/.

123 Lynne Cohen, "Law \& Disorder: Are Parole Officers Dodging the Nasties?" (8 July 2002) The Report 34 online: High Beam Research <http://www.highbeam.com/doc/1G1-94046060.html>.
} 
the process such that the Parole Board can be convinced that releasing Aboriginal inmates who apply for parole is good and safe.

An actuarial risk assessment of whether the offender is likely to re-offend constitutes an important factor considered by the Parole Board in whether to grant or deny parole. ${ }^{124}$ Tanya Rugge asserts that while there are a number of different instruments and methodologies for assessing offender risk, there is a general consensus about eight central risk factors:

1. history of antisocial behaviour,

2. antisocial personality,

3. antisocial attitudes,

4. antisocial peers,

5. family/marital problems,

6. school/employment difficulties,

7. absence of positive leisure or recreational activities, and

8. substance abuse. ${ }^{125}$

Factors such as antisocial peers and substance abuse are considered dynamic factors, or factors that can change over time with sufficient treatment. ${ }^{126}$ On the other hand, history of antisocial behaviour (i.e. criminal history) is a static factor, a stable factor that is not deemed to "change over time." ${ }^{127}$ According to Moore's study, percentages of inmates who were assessed as a high-risk to re-offend were 85\% for the Inuit, $73 \%$ for First Nations, $67 \%$ for the Metis, and 57\% for nonAboriginal inmates.

Some research has indeed concluded that criminal history is a reliable risk predictor for both Aboriginal and non-Aboriginal inmates. ${ }^{129}$ These studies, however, ignore that colonial oppression and the enduring social conditions that it has left behind continue to play a critical role in Aboriginal over-incarceration. To the extent that oppressive social conditions do much to bring Aboriginal peoples into contact with the justice system, the emphasis on static factors tied with criminal history may represent a form of systemic discrimination.

Moreover, the finding that criminal history is linked to re-offending in Aboriginal peoples ignores that that there is strong statistical evidence that Aboriginal spiritual healing can produce remarkably positive results with respect to recidivism post-release, This provides strong indications that Aboriginal spiritual healing has the capacity to address risk factors and prevent recidivism and ultimately suggests that where Aboriginal inmates are concerned, static factors should be de-emphasized in favour of dynamic factors. Moreover, the John

124 J. Nuffield, Parole Decision-Making in Canada: Research Towards Decision Guidelines (Ottawa: Solicitor General, 1982).

125 Risk Assessment of Male Aboriginal Offenders: A 2006 Perspective (Ottawa: Public Safety and

126 Emergency Preparedness Canada, 2006) at i, 6.

Ibid at i-ii.

127 Ibid at i.

128 Supra note 96 at 23.

129 J. Bonta, "Native Inmates: Institutional response, risk, and needs" (1989) 31 Can J Crim 49; J. Bonta, Carol LaPrairie, \& S. Wallace-Capretta, "Risk Prediction and Re-offending: Aboriginal and non-Aboriginal Offenders" (1997) 39 Can J Crim 127; J. Bonta, S. Lipinski, \& S. Martin, "The Characteristics of Aboriginal Recidivists" (1992) 34 Can J Crim 517. 
Howard Society has questioned the reliance on static factors in assessing recidivism and encouraged instead an emphasis on dynamic factors by corrections and parole officers.

Dynamic factors have been found to predict recidivism as well as, or better than, static factors and are also measured by several actuarial risk assessment tools. It is knowledge of dynamic factors that is necessary in order to assess changes in an offender's risk level. Through participation in rehabilitative programming, an offender may become less likely to recidivate, but corrections and parole workers would not be able to measure this change unless they assessed the offender's risk based on changeable factors.

Accordingly, actuarial risk assessment of Aboriginal offenders should deemphasize static factors, and instead focus on participation in culturally appropriate programming and spiritual healing, along with attendant offender progress in addressing dynamic risk factors. Culturally appropriate programming and spiritual healing can mould Aboriginal inmates' behaviours such that they can prepare themselves for parole and re-integration.

\section{ABORIGINAL GANGS AND PAROLE}

Concerns about the over-incarceration of Aboriginal peoples in Canada and the need for Aboriginal based rehabilitation programming must grapple with the particularly thorny issue of the prevalence of Aboriginal gangs in the prison system. Aboriginal gangs now exist in significantly large numbers, and with every expectation of expanding their numbers. Bob Bazin of the Canadian Institute of Strategic Studies estimates that there are twelve Aboriginal gangs with membership exceeding 500. ${ }^{131}$ Edmonton alone also has twelve gangs with membership exceeding 400 as of 2003 . $^{132}$ Aboriginal gangs have their genesis in the Canadian penal system when Aboriginal inmates formed associations to protect each other from rival inmates, such as biker or white supremacist inmates. Eventually, however, they morphed from groups that offered each other protection against outsiders to groups that generated their own forms of violence. The Criminal Intelligence Service of Canada reports:

In Alberta, Aboriginal-based gangs that once existed primarily in prisons for protection purposes have now recognized the financial benefit of trafficking hard drugs (e.g. cocaine) on

130

John Howard Society, Offender Risk Assessment (Edmonton: John Howard Society, 2000) at 3. The studies being referred to are P. Gendreau, T. Little \& C. Goggin, A meta-analysis of the predictors of adult offender recidivism: What works! (Ottawa: Public Works and Government Services Canada, 1996); R.K. Hanson \& M.T. Bussière, Predictors of sexual offender recidivism: A meta-analysis (Ottawa: Public Works and Government Services Canada, 1996).

131 "Police Tackle Growth of New Gangs Across the Province" Lloydminister Meridian Booster (23 March 2005) A10.

132 "Native Gangs on the Rise: 10 Percent of Edmonton Aboriginal Community Struggling" Daily Herald-Tribune (11April 2003) 8. 
reserves. Many of the gangs have ready access to weapons, including firearms, that has resulted in a number of incidents of violence.

As of 2005 there were an estimated 437 inmates in the federal system with Aboriginal gang affiliation, with only biker gangs having greater affiliation. ${ }^{134}$

There is no doubt that prison gangs present real security concerns. One study found that to a statistically significant level, junior gang members were more likely to commit violent offences within the American prison system than inmates who were not affiliated with gangs. ${ }^{135}$ The same study found, however, that inmates who had spent longer periods in prison were not significantly more likely to commit violent offences than unaffiliated inmates. ${ }^{136}$ The study was uncertain as to whether this reflected the accumulated stress of gang activity on an inmate's life or whether this reflected moving up in the gang hierarchy and therefore reflected the capacity to give orders instead of having to carry them out. ${ }^{137}$ Aboriginal gangs can present real safety problems for both inmates and correctional staff. Guards at the Edmonton Institution, a maximum security facility, reported that Aboriginal gang members frequently assaulted other inmates as part of the competition for the lucrative prison drug trade, and to keep the other inmates intimidated. ${ }^{138}$ They also are not afraid to take violent "runs" at the prison guards.

It has been argued that by voluntarily joining up with a gang, an Aboriginal inmate has engaged in self-labeling as one given to criminal activity and therefore merits greater scrutiny for the sake of both institutional and public safety. ${ }^{140}$ Aboriginal inmates however have frequently complained that they face discrimination when it comes to correctional officials denying them access to available programs. ${ }^{141}$ Many Aboriginal inmates perceive a double jeopardy effect underlying this discrimination. Correctional staff penalize them once for being Aboriginal offenders, and again for being identified as members of an Aboriginal prison gang. ${ }^{142}$

A frequent approach by Canadian correctional officials has been to try and keep Aboriginal gang inmates segregated from each other, and sometimes even to

1332003 Annual Report on Organized Crime in Canada (Ottawa: Criminal Intelligence Service Canada, 2003) at 5.

134 Kathleen Harris, "Federal Jails Hit by Gang Mentality" The Ottawa Sun (25 February 2005) 6.

135 Gerald G. Gaes et al., "The Influence of Prison Gang Affiliation on Violence and other Prison Misconduct" (2002) 82:3 The Prison Journal 359 at 369-370. For a study about the perception of American correctional officials that gang affiliated inmates were more likely to assault inmates than un-affiliated inmates, see Rick Ruddell \& Scott H. Decker \& Arlen Egley Jr., "Gang Interventions in Jails: A National Analysis” (2006) 31:1 Crim Just Rev 33.

Gaes, ibid at 374.

137 Ibid at 374-378.

138 "Who's Running the Joint: Prison Guards Say Native Gangs are Booming Under the Soft Regime at the Edmonton Max" Alberta Report (16 August 1999) 18-19.

139 Ibid.

140 Ovide Mercredi, Aboriginal Gangs: A Report to the Correctional Service of Canada on Aboriginal Youth Gang Members in the Federal Corrections System (Ottawa: Correctional

141 Service of Canada, 2000) at 7.

142 Ibid. 
keep Aboriginal inmates segregated from members of rival Aboriginal gangs. ${ }^{143}$ One report describes the fallacies of such an approach:

The next stage in the process is the segregation of known gang members. Gang members are isolated in units of their own and kept separate from other rival gangs. There are several problems with this approach. First and foremost, it is an attempt at "accommodation" of the gang phenomena and does directly deal with the root causes of the problem. When we segregate gangs, we are essentially throwing our hands up in despair and saying that the only way that we can control the situation is by trying to "manage" them by monitoring their movement and activities and making sure they do not interact with other gangs. This approach puts an onerous strain on correctional officers who have to be vigilant in keeping track of which group members are where at what time. Secondly, this approach leads to increased tensions in institutions as gang members, encouraged in their agitation and animosity through segregation, search for opportunities to threaten and intimidate rival gang members (through glass windows, doors, open access areas).

Approaches to gang activity may not however always require an iron fisted approach. It is possible for more conciliatory or rehabilitative approaches to make progress and discourage gang affiliation. One Canadian study found that rehabilitative programs that emphasize cognitive-behavioural therapy reduced recidivism for major institutional offences among treated gang members by $20 \%$ in comparison to untreated gang members after a two year follow-up. ${ }^{145}$ The study also concluded that the one-time $\$ 100,000$ cost for treating a gang member made such an approach more cost effective relative to the enormous year to year cost of housing criminals in the long-term.

Alternatives with an Aboriginal cultural emphasis have also been proven effective in dealing with problems presented by gang affiliation. An illustrative example, albeit not one that occurred in a prison setting, comes from Manitoba. The objective of the Ogijiita Pimatiswin Kinamatwin program is to facilitate a transition towards a better lifestyle for members of Aboriginal street gangs. ${ }^{147}$ Participants learn carpentry skills and help develop or improve housing in innercity areas. ${ }^{148}$ The program did not necessarily require the participants to cut ties

143 Jana Grekul, "When You Have Nothing to Live For, You Have Nothing to Die For": An Investigation into the Formation and Recruitment Processes of Aboriginal Gangs in Western Canada (Ottawa: Public Safety Canada - Aboriginal Corrections Policy Unit, 2006) at 59.

144 Ibid at 75

145

Chantal Di Placido et al., "Treatment of Gang Members Can Reduce Recidivism and Institutional Misconduct" (2006) 31:1 Law \& Human Behavior 93 at 108.

146 Ibid at 109.

147 Lawrence Deane \& Denis C. Bracken \& Larry Morrissette, "Desistance within an Urban 148 Aboriginal Gang" (2007) 54:2 Probation Journal 125 at 128-129.

Ibid. 
with fellow gang members, but only to desist from further criminal activity. ${ }^{149}$ From 2001 to 2006, 34 participants, some of them with extensive criminal histories that included drug related and violent offences, took part in the program. None of the participants were ever arrested during that period.

One Canadian maximum security prison tried a more conciliatory approach in addressing the problem of Aboriginal gangs in prisons, called the Dynamic Intervention Approach. ${ }^{151}$ Measures employed in this approach include correctional officers learning about the individual situations of the inmates, speaking with and listening to inmates, taking steps to address concerns expressed by individual inmates, ensuring access to educational and correctional programming for inmates, and ensuring access for Aboriginal inmates to Elders in pursuit of spiritual healing. ${ }^{152}$ The components of this approach included; widely understood guidelines for proper inmate behaviour, and a truce between correctional officers, Aboriginal inmates, and the general prison population, that led to a relatively safe and stable environment thereafter.

Some Aboriginal inmates who were interviewed in a consultation study expressed the view that gang affiliation is not a static matter, and that Aboriginal inmates are often willing to disassociate from prison gangs in order to reform behaviour or seek healing. ${ }^{154}$ The problem is that the gang member label stays with the offenders despite their positive efforts, impairing their ability to improve their security classification, and seek Elder healing and culturally appropriate programming. ${ }^{155}$ The study recommended that Correctional staff adopt a more flexible approach that gauges a commitment and willingness to disassociate from the gang lifestyle and begin reformation, thereby increasing inmates' access to needed resources. ${ }^{156}$ Perhaps these concerns could be incorporated into or addressed by an Aboriginal-specific classification scale that emphasizes progress with spiritual healing, cultural programming, and behavioural progress. A number of avenues for increasing the role of Aboriginal culturally appropriate programming and spiritual healing in facilitating corrections and parole have been explored in this paper, but whatever the merits of these avenues may be, there remain significant political obstacles to realizing them in Canada.

\section{POLITICAL OBSTACLES}

Policies that place Aboriginal inmates in lighter security classifications, grant parole more frequently and sooner can spark political opposition in Canada. Public opinion surveys in common law jurisdictions frequently express dissatisfaction with the performance of parole boards as contributing to the unduly lenient

\footnotetext{
149 Ibid.

150 Ibid.

151 Grekul, supra note 143 at 60.

152 Ibid at 60-69.

153 Ibid at 61-62.

154 Mercredi, supra note 140 at 14.

155 Ibid at 14-17.

156 Ibid at 17.
} 
treatment of convicted offenders. ${ }^{157}$ For example, a 1998 poll found that of all the institutions of justice in Canada, the Parole Board enjoyed the least confidence from the public. ${ }^{158}$ Only $4 \%$ of respondents had "A Lot" of confidence in the Parole Board in comparison to $38 \%$ for the R.C.M.P., while $31 \%$ said they had "Little" confidence and 26\% said they had no confidence at all in the Parole Board in comparison to $10 \%$ and $5 \%$ respectively for the R.C.M.P. ${ }^{159}$ As well, $65 \%$ of respondents indicated that they would like to see the parole system made stricter. ${ }^{160}$

Brandon Applegate and Robin King Davis note the political obstacles that often arise when trying to implement more rehabilitative approaches in prisons. They state:

However, such efforts can be difficult to implement when there are political barriers. The public's views on what should be done with people who break the law, for example, help to establish the boundaries of policy choices.

Public opinion cannot be easily ignored.

However, a study by Anthony Doob suggests it is not necessarily a given that the Canadian public will insist on longer and tougher punishments no matter what. ${ }^{162}$ Doob acknowledges that public opinion surveys often indicate the attitude that sentences are not harsh enough. He contends however that a more complex picture emerges if people are asked more specific questions about justice objectives and methods. ${ }^{163}$ When asked if they thought that increasing sentence terms was the best way of reducing a crime, less than a third of the respondents in his survey answered in the affirmative while the majority preferred alternatives such as reducing unemployment and developing social programs. ${ }^{164}$ When confronted with a hypothetical that involved the prisons being full, almost two thirds preferred reliance on sentencing alternatives to building more prisons. ${ }^{165}$ Over $80 \%$ indicated that when a sum of money to spend on justice was available, it was better to invest it in preventative measures rather than prisons. ${ }^{166}$ Doob then presented the respondents with a hypothetical scenario involving a first time break and enter. When confronted with a reminder that the monthly cost for imprisoning an offender ranged from $\$ 3,700$ to $\$ 6,000,84$ to $86 \%$ preferred a conditional

\footnotetext{
157 Julian V. Robert, "Early Release: What do the Canadian Public Really Think?" (1988) 30:3 Can J Crim 231; T. Flanagan \& D. Longmire, Americans view Crime and Justice: a National Public Opinion Survey (Thousand Oaks, California: Sage, 1996); M. Hough \& Julian V. Roberts, Attitudes to Punishment: Findings from the British Crime Survey (London: Home Office, 1998). 
sentence and fine to jail. ${ }^{167}$ Perhaps if the Canadian public was made aware that Aboriginal approaches to corrections are not only effective, but also cost-effective in the long run, then the federal government may be able to secure a political mandate to implement the suggestions for reform that have been made here.

There are specific examples of support for new approaches in the United States. A recent example of the ability of policy makers to mould public opinion to become more supportive of community-based alternatives comes from Kansas. In 2006, Kansas policy makers were faced with the prospect of their prison population increasing by $26 \%$ by 2016 , with the costs of building and operating additional prisons increasing by at least $\$ 500$ million. ${ }^{168}$ In 2007 , the policy makers solicited public opinion through the "Kansas Criminal Justice Public Opinion Survey." ${ }^{109}$ The results indicated overwhelming support for increasing the availability of rehabilitation programs to inmates, and splitting the corrections budget between the programs and new prisons, as opposed to just spending it on more prisons. ${ }^{170}$ Kansas policy makers, interpreting the survey as a confident mandate, reinvested $\$ 7$ million into treatment programs and community supervision services that otherwise would have been spent building more prisons. ${ }^{171}$

In 2000, California voters showed overwhelming support for Proposition 36, a mandate to end mandatory sentencing for drug offences, and instead emphasize probation plus treatment for drug offenders. ${ }^{172}$ In the background of this development was an awareness of the high costs for California tax payers as the prisons were overcrowded and operating at $172 \%$ capacity and the annual costs of maintaining a prisoner ranged from $\$ 42,000$ to $\$ 55,000$ each year. ${ }^{173}$

It is important to keep in mind that successful rehabilitative efforts address a longstanding and legitimate concern of the voting public; their safety. James Le Blanc, Secretary of the Louisiana Department of Public Safety and Corrections, writes:

Indeed, we should not underestimate the role offender reprogramming plays in overall safety and security in our communities. Reentry initiatives play a crucial role in changing the behavior of the population we serve. For most of us, the focus on reentry is a culture of change - for management, staff, offenders and communities. It is also difficult for most lawabiding citizens to swallow because they believe prison should be punitive, not an opportunity for advancement. What we should keep reminding everyone is that people currently behind

\footnotetext{
167 Ibid at 334-335.

168 Crystal Garland, "Increasing Public Safety and Reducing Spending: Applying a Justice Reinvestment Strategy in Texas and Kansas” (2007) 69:6 Corrections Today 64 at 64.

169 Ibid at 66.

170 Ibid.

171 Ibid.

172 Nathaniel J. Pallone \& James J. Hennessy, "To Punish or to Treat: Substance Abuse within the Context of Oscillating Attitudes Toward Correctional Rehabilitation" (2003) 37:3/4 Journal of Offender Rehabilitation 1 at 13.

Ibid.
} 
bars will eventually return to their communities. It is in everyone's best interests that they return with the education, skills and access to services that will ensure success. There will be some people that we can never change, no matter how hard we try, because they will not allow change to happen. But there are many individuals who haven't had the opportunity for change, and strong reentry programming, whether it be educational, vocational, faith-based or a combination thereof, provides that opportunity for change. ${ }^{174}$

This potentially represents another selling point to Canadian voters: Aboriginal culturally appropriate approaches are not only effective, but may also enhance public safety as well.

\section{CONCLUSION}

Certainly the problem of Aboriginal over-incarceration can be addressed to a large degree by initiatives outside the prison system itself. Examples include restorative justice programs, and economic development programs that can give Aboriginal peoples opportunities to lead fulfilling lives that are not fuelled or hampered by crime. Nonetheless, there is a real need to address the problem at its destination. It is in federal prisons where we have many Aboriginal inmates whose lives are deeply fractured. It is in federal prisons where we have an opportunity to effect real and positive change. The concerns about systemic discrimination expressed by scholars like Howard Sapers and by Aboriginal inmates themselves can be addressed by more than one avenue. Allocating greater resources for culturally sensitive programming for Aboriginal inmates is imperative. The idea is "spend now, save later." Aboriginal inmates who successfully reform and reintegrate will represent the better long term investment than Aboriginal inmates who stay warehoused in prisons year after year. Criminal history is a static factor for security classification purposes that may have little predictive value for Aboriginal inmates' security risk, and therefore should be de-emphasized. Greater emphasis should be placed on Aboriginal participation in spiritual healing and culturally appropriate programming, along with behavioural progress as a more appropriate method of gauging actual risk. Risk assessment to re-offend for purposes of parole should also be adjusted along similar lines. Aboriginal gang activity can be addressed with a more flexible system that de-emphasizes past involvement and instead gauges a willingness to reform and dissociate from the gang lifestyle. There will undoubtedly be political opposition to such measures, however, there are indications that it is possible to obtain a political mandate to implement alternative approaches if the public is made aware of the benefits that can be gained.

174 James Le Blanc, "Rehabilitation Programs Will Help Offenders Change - And Enhance Public Safety" (2008) 70:5 Corrections Today 8 at 8 \& 14. 


\section{DIZZYING DIALOGUE: CANADIAN COURTS AND THE CONTINUING JUSTIFICATION OF THE DISPOSSESSION OF ABORIGINAL PEOPLES}

\section{D'Arcy Vermette}

Since Aboriginal rights have found protection within Canada's Constitution, a new relationship has emerged between Canada's Aboriginal Peoples and the Crown. This relationship is characterized by the need for "reconciliation." In its growing jurisprudence, the Supreme Court of Canada applies reconciliation doctrine to several important Aboriginal claims. Each application, however, brings with it a restriction on Aboriginal rights. This paper argues that the Court's conception of reconciliation is designed to facilitate the integration of Aboriginal peoples into larger society rather than to protect their collective interests. To demonstrate this argument, this paper examines the Supreme Court's discussion of the doctrine of reconciliation from Sparrow (1990) to Little Salmon (2010).

Depuis que les droits des autochtones sont protégés par la constitution canadienne, une nouvelle relation, ayant comme caractéristique le besoin de "réconciliation », a vu le jour entre les peuples autochtones du Canada et la Couronne. La Cour suprême du Canada a appliqué la doctrine de la réconciliation dans la série d'arrêts où elle s'est penchée sur plusieurs importantes revendications autochtones. Dans chaque cas, l'application de la doctrine de la réconciliation a cependant abouti à une restriction des droits des autochtones. Dans cet article, l'auteur soutient que, dans l'esprit de la Cour, la réconciliation vise à faciliter l'intégration des peuples autochtones dans la société en général plutôt qu'à protéger leurs intérêts collectifs. Pour étayer cette opinion, il examine l'analyse qu'a faite la Cour suprême de la doctrine de réconciliation de l'arrêt Sparrow (1990) à l'arrêt Little Salmon (2010).

Of the Métis Nation. Assistant Professor, Native Studies Programme, St. Thomas University LL.D. Candidate, LL.M., LL.B., B.A. (Native Studies). Thank you to Reem Bahdi for the helpful editorial suggestions and for showing patience in seeing my work to the finish line. This paper is dedicated to the memory of Patricia Monture. When I was an undergraduate student, Patricia showed me that the power of Aboriginal understanding does not lie within the minutiae of our individual experience (for these are symptomatic responses) but in our ability to build an intellectual understanding of the forces which disempower our People(s). Her message was one which provided a way forward for the judiciary and which was artfully captured in her writing. Thank you, Trisha, for your teachings and inspiration. 
Canadians must carefully examine their past and present relationships with Aboriginal Peoples in an effort to take themselves to the place where they understand what is required to move beyond the colonial relations on which the country is based.

\section{INTRODUCTION}

Studying, researching, and writing about Aboriginal law can be a grinding and exhausting experience. Try as Aboriginal scholars and commentators might to encourage Canadian courts to approach their relationship with Aboriginal peoples in a different, non-colonialist light, it appears that very little listening is taking place. Instead, courts adopt language and propose concepts that appear enlightened on their face but that actually are limited to formalizing the process of colonization. Colonialism "exploits the oppressed people, destroying their national society and replacing Indigenous cultures." This exploitation is achievable because Aboriginal peoples are made into objects that, dehumanized, are easily exploitable and dominated. "Under colonialism society is transformed...The imperialists produce and appropriate economic surpluses that set into motion inferior class and cultural inferiority of the Indigenous population." ${ }^{3}$ Domination becomes the key factor applicable to the virtual totality of Aboriginal/newcomer relations.

"Reconciliation" has recently emerged as an overarching theme in Aboriginal law. While reconciliation is undoubtedly a nice, attractive word, no reconciliation is actually taking place or being built as a result of or in relation to Canada's laws concerning the rights of Aboriginal peoples. ${ }^{5}$ On the contrary, in recent years Canada's courts have created and interpreted a principle of reconciliation which embodies (some) nice language but offers little reconciling substance. Canadian courts are confused (or dishonest) because '[i]n 'truth'... there never was any 'conciliation' to 're", This paper discusses the court's interpretation, and misapplication of the reconciliation principle; it reveals a process of domination within the realm of reconciliation.

When Aboriginal rights were enshrined in the Constitution in 1982, it was an act of redress which had the potential to open the doors to a broader reconciling process. But reconciliation was not the legal buzz word of the time. Reconciliation only emerged as a legal principle when constitutionally protected Aboriginal rights reached the Supreme Court of Canada in 1990. The Supreme Court of Canada

\footnotetext{
Patricia Monture-Angus, Journeying Forward: Dreaming First Nations' Independence (Halifax: Fernwood Publishing, 1999) at 22.

2 Howard Adams, Tortured People: The Politics of Colonization, revised ed. (Penticton, B.C., Theytus Books Ltd., 1999) at 6.

Ibid.

Ibid at 7.

5 While this paper is about the case law, reconciliation is occurring in other contexts. For a look at the Government of Canada's attempt at reconciliation in regards to residential schools, see R. Chrisjohn \& A. Bear Nicholas, et al. "An Historic Sort-of-Apology, Completely and Utterly Not Accepted" online: The Marxism Mailing List <http://www.marx- mail.org/Apology-NotAccepted.htm>.

$6 \quad$ Ibid.
} 
introduced reconciliation with a coherent vision. Indeed, the language of the Sparrow $^{7}$ decision, bears witness to this vision. But post-Sparrow, the Supreme Court began to apply reconciliation in a variety of ways, each of which diverted considerably from the Sparrow approach.

This paper offers a critique of the Supreme Court of Canada's doctrine of reconciliation from its beginnings in Sparrow to its most recent application in Little Salmon. ${ }^{8}$ Little Salmon cannot be understood without the legal context which preceded it. This paper establishes the proper jurisprudential context for Little Salmon by demonstrating how the Court's colonialist understanding of reconciliation has led to yet another defeat for Aboriginal issues in Canadian courts. Part II of this paper unpacks the various ways in which the Supreme Court of Canada interprets the principle of reconciliation by following the evolution of the principle in key Aboriginal rights decisions. It argues that reconciliation represents an arbitrary creation of the court. As a principle, it remains disconnected from Aboriginal aspirations and has in fact produced the continued dispossession of Aboriginal peoples through law. Part III examines how the doctrine of reconciliation has played out in regards to duties owed to Aboriginal Peoples. It follows the doctrine of reconciliation through the major cases on the duty to consult which culminates in the Little Salmon decision. Here it is argued that the way in which reconciliation is employed by the Court illustrates the arbitrariness of the principle and the unwillingness of the Court to compromise its colonial mentality.

\section{THE PARADOX OF THE DOCTRINE OF RECONCILIATION ${ }^{9}$}

The principle(s) of reconciliation as articulated by the Supreme Court has received insufficient academic attention in Canada, although two scholars have examined the important concept in some detail. Professor Kent McNeil has explored the conflicting notions of reconciliation articulated in the majority opinions articulated by Chief Justice Lamer as compared to the dissenting opinions of current Chief Justice McLachlin. ${ }^{10}$ McNeil concludes that McLachlin's views are "more in keeping with the constitutional principles that should govern the relationship between Aboriginal peoples and the Crown." "Professor McNeil has adequately explored the inner conflict of the Court and I do not intend to repeat that work although I do discuss Chief Justice McLachlin's dissenting opinion in the Van der Peet ${ }^{12}$ trilogy of cases in my own analysis. While I draw inspiration from McNeil's approach and analysis of the Lamer-McLachlin debate, I go beyond this internal debate and examine a larger swath of Canadian jurisprudence.

\footnotetext{
R. v Sparrow, [1990] 1 S.C.R. 1075 [Sparrow].

8 Beckman v Little Salmon/Carmacks First Nation, 2010 SCC 53 [Little Salmon].

9 Thank you to Patricia Monture for directing my attention to the changing use of this concept. The analysis here is my own. My first treatment of this topic can be found in Colonial Oppression and the Law: Myth, Voice, Culture and Identity in Aboriginal Rights Discourse (LL.M Thesis, Queen's University, Faculty of Law, 2004) [Unpublished].

10 Kent McNeil, "Reconciliation and the Supreme Court: The Opposing Views of Chief Justices Lamer and McLachlin” (2003) 2 Indigenous LJ 1.

11 Ibid at 3-4.

12 R. v Van der Peet [1996] 2 S.C.R. 507 [Van der Peet].
} 
Professor Mark Walters has also recently examined reconciliation in Aboriginal rights jurisprudence. ${ }^{13}$ Walters conceives of reconciliation in three broad themes and applies Aboriginal rights jurisprudence to those themes. I employ the reverse process in this paper, extracting reconciliation themes from the case law in order to determine how the Court uses its discretion in its reasoning process. All of the themes of reconciliation identified by Walters "involve finding within, or bringing to, a situation of discordance a sense of harmony.", I take no issue with this general understanding of reconciliation. However, it does not reflect the content found in the practice of the Supreme Court of Canada. Indeed, little harmony is brought to Aboriginal/Crown conflicts through the Supreme Court's use of the principle of reconciliation.

I identify three characterizations of reconciliation within the Court's jurisprudence: a "constitutional reconciliation" as applied in Sparrow, a "historical reconciliation" as applied in Van der Peet, and a "contemporary reconciliation" as applied in Gladstone. ${ }^{15}$ Each form of reconciliation creates an unjustified burden on s. 35 rights and each represents a different tool available to Canadian courts to limit Aboriginal rights claims in subtle but devastating ways. Scholars have pointed out the extent to which Canadian law oppresses Aboriginal peoples. ${ }^{16}$ Similarly, my purpose is to reveal the premises and assumptions which the Supreme Court of Canada uses to justify the operation of Aboriginal rights. By becoming more aware of these legal burdens we can identify which areas of Canadian law need a massive re-evaluation and a more honest critique from the Courts before we can even begin to talk about true reconciliation. In the alternative, a true process of reconciliation could very likely embody no role for Canada's courts.

\section{A. Constitutional Reconciliation}

The Supreme Court's original exploration of reconciliation occurred in the 1990 Sparrow decision. ${ }^{17}$ This constitutional reconciliation was focused solely on the duties and powers associated with Crown action. At that time, the Court

13 Mark Walters, "The Jurisprudence of Reconciliation: Aboriginal Rights in Canada" in Will Kymlicka and Bashir Bashir eds, The Politics of Reconciliation in Multicultural Societies (New York: Oxford University Press, 2008) 165.

14

Ibid at 167. Perhaps the most pertinent expression of reconciliation which Walters identifies in Aboriginal rights jurisprudence is what he terms "reconciliation as relationship" which, at 168, he states is "about peace between communities divided by conflict, but it is also about establishing a sense of self-worth or internal peace within those communities."

15 R. v Gladstone [1996] 2 S.C.R. 723 [Gladstone].

16

This literature is extensive, however two of my favorites are Patricia Monture-Angus, supra note 1 and Gordon Christie, "A Colonial Reading of Recent Jurisprudence: Sparrow, Delgamuukw and Haida Nation" (2005) 23 Windsor YB Access Just. 17. Christie offers nine possible models for how the law could have interpreted its relationship with Aboriginal peoples. His conclusion is that the second most restrictive model has been employed in Canada. Christie's analysis and conclusion illustrates that we are engaged in a continuing process of domination which subjects Aboriginal peoples to the whims of the colonial government (now Canada). It is in recognition of this ongoing relationship that I refer to the Supreme Court of Canada as a colonial court.

Walters, supra note 13 at 176, mistakenly identifies Van der Peet as being "the first in a long series of judicial decisions on reconciliation and Aboriginal rights." It is clear that Sparrow, which was decided in 1990, represents the Supreme Court's original exploration of this principle. Perhaps Walters' use of Van der Peet as a starting point represents a distinction of the kind outlined in this paper, that reconciliation as outlined in Sparrow does not directly involve Aboriginal peoples. This is not made clear in his work. 
asserted that "...federal power must be reconciled with federal duty and the best way to achieve that reconciliation is to demand the justification of any government regulation that infringes upon or denies aboriginal rights." "I I term this "constitutional reconciliation" because it is rooted in "federal powers" such as those in section 91(24) which gives the federal government jurisdiction over "Indians, and lands reserved for the Indians", and in "federal duty" which encompasses the fiduciary relationship present between the Crown and Aboriginal peoples. ${ }^{20}$ By reconciling federal powers and federal duties, reconciliation began as a burden placed on the actions of the federal government. Indeed, reconciliation was understood as being a requirement that the federal government justify its infringement on an Aboriginal right. Even though Aboriginal peoples are not directly involved in this process of reconciliation, they are of course certainly impacted by it. As a burden on government actions, reconciliation was cast as a means of protecting Aboriginal rights from unchecked federal power.

But, the reconciliation conceived of in Sparrow produced dangerous consequences for Aboriginal rights. Oddly and ironically, discussions of reconciliation initially came about as a result of justifying limitations on section 35(1) which demands simply that "the existing aboriginal and treaty rights of the aboriginal peoples of Canada are hereby recognized and affirmed.", Section 35 does not include a limitation clause within its terms nor does it fall under section 1 of the Charter. ${ }^{22}$ Since the drafters of the Constitution Act were well aware of limitation clauses, one would expect that in the absence of such a clause there would be no internal limits imposed by the courts upon the existing Aboriginal and treaty rights of the Aboriginal peoples. However, using the principle of reconciliation, the Supreme Court of Canada imported a justification test into the relationship between Aboriginal peoples and the government of Canada. This test allows the colonizer to infringe on Aboriginal rights, as long as it can be justified according to the criteria established by the Supreme Court. ${ }^{23}$ Such a reading of

18 Sparrow, supra note 7 at para 62. The justification test, as laid out in Gladstone, supra note 15 at para 54 requires that "the government must demonstrate that it was acting pursuant to a valid legislative objective" and "the government must demonstrate that its actions are consistent with the fiduciary duty of the government towards aboriginal peoples." Gladstone formed one third of the "Van der Peet trilogy". The third case was R. v N.T.C. Smokehouse Ltd. [1996] 2 S.C.R. 672. Gladstone was a fishing rights case.

19 Constitution Act, 1867 (U.K.), 30 \& 31 Vict. c. 3, s. 91(24) (formerly the British North America Act, 1867) reprinted in R.S.C. 1985, App. II, No. 5.

20 Aboriginal and treaty rights jurisprudence has set out other duties such as the duty to consult Aboriginal peoples. As well, although not a duty in the proper sense, the "honour of the Crown" is a principle which governs Crown action. Also see, Leonard I. Rotman, "Aboriginal Rights: Crown-Native Relations as Fiduciary: Reflections Almost Twenty Years After Guerin" (2003) 22 Windsor YB Access Just 363 (QL) at n 45 where he explains that while the reconciliation in Sparrow was pointed at federal powers, "A similar effect was imposed upon provincial legislative competence in respect of Aboriginal peoples, as indicated in the Court's finding that section 35(1) 'affords Aboriginal peoples constitutional protections against provincial legislative power."' Constitution Act, 1982, s. 35(1) being schedule B to the Canada Act, 1982 (U.K.), 1982, c. 11.

22 Canadian Charter of Rights and Freedoms, Schedule B, Constitution Act, 1982 (U.K.) 1982, c. 11. Charter rights may be limited if the limitation is "demonstrably justified in a free and democratic society".

23 Larry Chartrand, The Political Dimension of Aboriginal Rights (LL.M Thesis, Queen's University, Faculty of Law, 2001) [Unpublished] at 103 he points out that the imposition of a justification test is inconsistent with the Court's prior stance on similar issues. 
section 35(1) could not possibly offer protection for Aboriginal rights and only serves to affirm Crown authority.

Rather than interpret section 35(1) according to the plain language embodied in the Act, the "reading in" of a justification test resulted in the Supreme Court disregarding one of its own rules of interpretation. In Nowegijick, the Supreme Court found that "... treaties and statutes relating to Indians should be liberally construed and doubtful expressions resolved in favour of the Indians." ${ }^{24}$ There is nothing favourable about a justification test which sanctions government infringement of Aboriginal rights. Indeed, without a limitation clause, section 35 (1) ought to have operated as an unreserved recognition of rights. "Recognition" and "affirmation" alone had the potential to introduce a newly prosperous era in Aboriginal/Crown relations. ${ }^{25}$ This potential was destroyed, in part, by the creation of a justification test which relies upon the assumed superiority of the Crown. Rather than merely imposing a burden on federal powers, constitutional reconciliation has become a burden on the full expression of section 35(1) Aboriginal rights.

\section{B. Historical Reconciliation}

A very different kind of reconciliation can be located in Van der Peet. Here, the Court sets out what I term historical reconciliation. In Van der Peet, reconciliation is presented as the reasoning behind section 35(1): "It is...the reconciliation of pre-existing aboriginal claims to the territory that now constitutes Canada, with the assertion of British sovereignty over that territory, to which the recognition and affirmation of aboriginal rights in s.35(1) is directed. ${ }^{, 26}$ Through this form of reconciliation the Court is focused on the historic relationship between Aboriginal peoples and the Crown. While this may be an accurate characterization of the purpose behind s. 35(1), when courts administer reconciliation, it furthers the process of domination experienced by Aboriginal peoples. In Van der Peet this restriction is accomplished by demanding that Aboriginal claims be reconciled with the assertion of British sovereignty. By mere assertion, Crown sovereignty is thus thrust upon Aboriginal people without question, justification or consent. The historical reconciliation set forth in Van der Peet is applied in addition to, rather than in place of, constitutional reconciliation. While reconciliation is thus no longer entirely focused on federal power and federal duty, the Court has retained the justification test.

Historical reconciliation was designed to ensure that the Aboriginal "perspective" is taken into account when considering the definition of an Aboriginal right. But the Court fails to achieve this goal in an equitable manner. The inequality takes shape in the Court's insistence that Aboriginal people accommodate the non-Aboriginal legal system in order to have their rights reconciled with Canadian sovereignty:

Nowegijick v The Queen, [1983] 1 S.C.R. 29, at 36.

Monture-Angus, supra note 1 at 47 where she writes: "'Recognize' means to acknowledge something that already exists. 'Affirm' means to embrace the rights which are now being recognized. To not accept that the words 'recognized and affirmed,' at a minimum, move us beyond thinking that western or European is superior renders the constitutional words meaningless."

26

Supra note 12 at para 36 [emphasis added]. 
The definition of an aboriginal right must, if it is truly to reconcile the prior occupation of Canadian territory by aboriginal peoples with the assertion of Crown sovereignty over that territory, take into account the aboriginal perspective, yet do so in terms which are cognizable to the non-aboriginal legal system. ${ }^{27}$

It is clear that under this system of reconciliation, Aboriginal laws never receive the status that is enjoyed by colonial laws. ${ }^{28}$ Larry Chartrand has noted that the Supreme Court's failure to give equal legal authority to Aboriginal legal systems ensures that "Aboriginal systems must do all the reconciling." ${ }^{29}$ This one-way street immediately casts the legal process of reconciliation in doubt. Indeed, the Supreme Court's failure to receive Aboriginal laws on equal footing with colonial laws does more to entrench the force of colonial law than it does to reconcile competing interests. ${ }^{30}$ As a result, the Court has created conditions in which it cannot actually provide a full recognition and affirmation of Aboriginal laws and rights. This failure is assured despite the Court's recognition of the importance of Aboriginal "perspective" these accommodations that their rights will be recognized and affirmed.

\section{Contemporary Reconciliation}

Another approach to reconciliation can be found in Gladstone. Here, the Court proposes to adopt the definition of reconciliation proposed in Van der Peet. However, the Court went beyond Van der Peet and introduced another conception of reconciliation. Rather than focusing on the past, the Court looks to reconcile contemporary conflicts. Contemporary reconciliation allowed the Court to further entrench limitations on Aboriginal rights. While talking about the participation of non-Aboriginal groups in the fishery as potentially satisfying the standard of infringement, the Court stated: "In the right circumstances, such objectives are in the interest of all Canadians and, more importantly, the reconciliation of aboriginal societies with the rest of Canadian society may well depend on their successful attainment. ${ }^{, 33}$ This adjustment in the definition of reconciliation sees a new limitation being imposed on Aboriginal people. After Gladstone it is necessary to

27 Ibid at para 49 [emphasis added].

For e.g. see R. v Delgamuukw [1997] 3 S.C.R. 1010 (S.C.C.) [Delgamuukw] where the Aboriginal laws are taken merely as evidence rather than as laws which can be interpreted and applied to people and land. Supra note 23 at 82 where Chartrand writes: "Aboriginal rights exist 'within' the legal system of Canada and not equal to it."

30 Peter Fitzpatrick, The Mythology of Modern Law (New York: Routledge, 1992) at 86: "The creation and enforcement of any law is a ritual reassertion of the foundational strength and ordering of the centre. What is being affirmed is not just a particular order in opposition to disorder but the very being and force of order itself." (note omitted)

31 Van der Peet, supra note 12 at para 50 where the Court writes: “...the only just and fair reconciliation is ... one which takes into account the aboriginal perspective while at the same time taking into account the perspective of the common law. True reconciliation will, equally, place weight on each."

32 Gladstone, supra note 15 at para 72-73.

33 Ibid at para 75 
reconcile Aboriginal claims with the "rest of Canadian society." As such, an Aboriginal claim has to be weighed against the needs of non-Aboriginal society.

Has such a process not already been accounted for in the establishment of section 35(1)? Isn't the balancing of Aboriginal and non-Aboriginal interests at the core of constitutional protection of Aboriginal rights? The choice to recognize and affirm Aboriginal rights in s. 35(1) established a path towards balancing the needs, wants and expectations of colonial society while at the same time protecting Aboriginal interests from the domination which accompanies the habituations of colonialism. While not framed in that light, the colonial context gives meaning to s. 35(1). By acknowledging this broader reality, the Supreme Court had the opportunity to give s. 35(1) some meaningful content. To date, the Supreme Court has avoided this path in its interpretation of section 35. Instead, the Court has chosen to retread the familiar path of colonialism. By incorporating the "rest of Canadian society" into the balancing exercise, the Court has expanded the doctrine of reconciliation in a way that further restricts the interpretation of Aboriginal rights. This development thus dictates that the needs of broader Canadian society are an important aspect when defining an Aboriginal right. Such a limitation cannot be justified in the wording of section 35(1).

\section{Reconciliation in Practice}

With 3 variants at its disposal, each of which imposes a particular burden on Aboriginal claims, the Supreme Court has invoked reconciliation discourse explicitly and implicitly in its consideration of Aboriginal claims. One example is found in Delgamuиkw ${ }^{34}$, a landmark decision, where the Court determined the content of Aboriginal title. The Court began by referring to the importance of conservation of fisheries as defined in Sparrow: "The conservation of fisheries ... seeks to reconcile aboriginal societies with the broader community by ensuring that there are fish enough for all., ${ }^{35}$ Here the Court is focusing upon the reconciliation of contemporary interests in order to attend to the needs of both Aboriginal society and "the broader community." As is so often the case, the unstated truths often prove the most poignant. In this instance, the Court fails to consider that even if such conservation does ensure fish for all, such reconciliation also imposes a limitation upon Aboriginal rights which is not justified in s. 35(1). The failing in such a limitation is that the conservation of fisheries results from the imposition of federal power over Aboriginal people, rather than through balancing interests through negotiation.

Constitutional reconciliation, which would demand an examination of the Crown's duties to Aboriginal peoples, recedes from view. Instead, the reconciliation theory advanced in Delgamuukw focuses on federal powers and the needs of broader society. The Court thus ensures that federal power continues to preside over protected rights while nonetheless speaking the language of reconciliation. From here the Court in Delgamuиkw explained that a wide variety of legislative objectives can infringe upon Aboriginal title:

The general principles governing justification laid down in Sparrow, and embellished by Gladstone, operate with respect to

\footnotetext{
Supra note 28.

Ibid at para 161.
} 
infringements of aboriginal title. In the wake of Gladstone, the range of legislative objectives that can justify the infringement of aboriginal title is fairly broad. Most of these objectives can be traced to the reconciliation of the prior occupation of North America by aboriginal peoples with the assertion of Crown sovereignty, which entails that "distinctive aboriginal societies exist within, and are a part of, a broader social, political and economic community". In my opinion, the development of agriculture, forestry, mining, and hydroelectric power, the general economic development of the interior of British Columbia, protection of the environment or endangered species, the building of infrastructure and the settlement of foreign populations to support those aims, are the kinds of objectives that are consistent with this purpose and, in principle, can justify the infringement of aboriginal title.

Strangely, the Court refers to historical reconciliation when undertaking what is clearly an assessment of the possible grounds of contemporary infringement. The inconsistencies that mark the Court's application of the reconciliation principles clearly displays the arbitrariness which underlie Aboriginal rights.

Moreover, by establishing that virtually any type of economic development can potentially infringe Aboriginal rights, the Court appears more concerned with protecting federal powers rather than protecting Aboriginal rights. The Court lost sight of the wording of section 35(1) and has maintained instead, its loyalty to the colonial state. There is nothing in the wording of section 35(1) demanding the Court reconcile any competing claims. Recognition and affirmation do not, on their own, allow the Court to permit any infringement of Aboriginal rights. Quite the contrary. But, by crafting its own reconciliation doctrine, the Court has removed the impetus for a negotiated settlement of Aboriginal claims.

Reconciliation reached new and even more expansive bounds in Justice Binnie's minority judgment in Mitchell v. Canada. Binnie's vision shows the extent to which the Court has diminished the protections enshrined in section 35(1). In an attempt to carry out a contemporary reconciliation Justice Binnie removes the Aboriginal from the Aboriginal interest. Under Binnie's vision, the Aboriginal interest in Mitchell, which involved bringing goods across the CanadaU.S. border without paying customs, was lumped together with those interests of broader society. Binnie begins this process by denying that the Aboriginal claim is compatible with sovereignty of the colonizer. Instead, Binnie chooses to recognize the importance of the Aboriginal claim by relating it to "...national interests that all of us have in common rather than to distinctive interests that for some purposes differentiate an aboriginal community. In my view, reconciliation of these interests in this particular case favours an affirmation of our collective sovereignty." ${ }^{38}$ Behind such a statement lurks the assumption that the colonial government is better positioned to manage the Aboriginal claim as part of "our collective sovereignty" than Aboriginal people are at managing their constitutional rights.

\footnotetext{
36 Ibid at para165 [notes omitted].

37 Mitchell v Canada (Minister of National Revenue - M.N.R.) [2001] 1 S.C.R. 911 [Mitchell]

38 Ibid at para 164.
} 
As Walters' notes, Justice Binnie fails to explain "how or when a legitimate sense of shared sovereignty or common citizenship was forged between Aboriginal and non-Aboriginal Canadians.." ${ }^{, 39}$ Just as Aboriginal peoples and lands are set aside as a separate sphere of federal jurisdiction, Aboriginal rights are protected as distinct rights under a dedicated constitutional provision. By melding the Aboriginal and Crown spheres, Justice Binnie fails to respect the unique position that Aboriginal rights hold in the Constitution. Rather than respecting the limited extent to which "our collective sovereignty" was set out in the Constitution, Binnie stifles the Aboriginal voice by devouring the Aboriginal interest.

Binnie's decision in Mitchell fails to recognize the distinctive political identity of the Aboriginal society which he is judging. He writes: "Whereas historically the Crown may have been portrayed as an entity across the seas with which aboriginal people could scarcely be expected to identify, this was no longer the case in 1982 when the s. 35(1) reconciliation process was established." ${ }^{40}$ Here again a Supreme Court justice neglects the plain language and ultimate purpose of section 35(1) which simply recognizes and affirms Aboriginal rights. Justice Binnie also seems to be working with an understanding that the colonization of Aboriginal peoples was completed in 1982 when he purports that this reconciliation process started. It is not a giant leap from such a false premise to the melding of Aboriginal claims with "national interests" and then on to the assertion that such a melding constitutes a process of reconciliation. In fact, Binnie's reasoning only serves to further disenfranchise Aboriginal people of the rights which had been guaranteed to them.

Larry Chartrand has pointed out the contradiction between the Court's asserted goal of reconciliation and the power structure that gives the Court the ability to make such an assertion: "The courts have held that it is the common law that forms the basis of interpreting Aboriginal rights. In other words, mainstream society has a monopoly over the legal system that is to be the basis for 'reconciling' Aboriginal and non-Aboriginal differences." ${ }^{\text {,11 }}$ This monopoly does not pose a problem for the federal government which asserts that the Supreme Court's decisions "have set the parameters within which reconciliation must occur.",

But, the federal government is not giving itself enough credit. Section 35(1) is an act of reconciliation. Section 35(1) already attempts to reconcile federal duties with federal responsibilities. Section 35(1) represents an act of reconciliation through the decision to simply recognize and affirm Aboriginal rights. The plain language of section 35(1) represents a withdrawal of at least some colonial power

\footnotetext{
Walters, supra note 13 at 179 .

Mitchell, supra note 37 at para 129.

Supra note 23 at 80

Statement by the Delegation of Canada to the Sixth Session of the United Nations Permanent Forum on Indigenous Issues, Agenda Item 3: Special Theme: Territories, Lands and Natural Resources, Delivered by: Daniel Watson, Senior Assistant Deputy Minister, Indian and Northern Affairs Canada. New York, May 16, 2007, online: Indian and Northern Affairs Canada <http://www.ainc-inac.gc.ca/ird/2007/tln_e.html>. Also see Monture-Angus, supra note 1 at 103 where she writes: "The Crown's relationship with Aboriginal people requires a higher standard of conduct even when they are adversaries. To allow litigation and the adversarial nature of this process to exempt the Crown from their obligations to Aboriginal people serves only one purpose and that is to continue to entrench colonial relations."
} 
over Aboriginal lives. Section 35(1) does not establish a reconciliation process to be carried out through the courts. It certainly does not purport to grant the courts such a large responsibility. Indeed, Justice McLachlin was critical of the majority's approach to reconciliation articulated in Van der Peet. In her dissenting opinion, McLachlin saw the Court's use of reconciliation as a political process which lacked precision:

At the broadest reach, whatever the government of the day deems necessary in order to reconcile aboriginal and nonaboriginal interests might pass muster... Upon challenge in the courts, the focus will predictably be on the social justifiability of the measure rather than the rights guaranteed. ${ }^{43}$

Focusing on social justifiability takes the Court away from the main task of ensuring that Aboriginal rights are simply "recognized" and "affirmed." Despite this astute insight into the fact that the process of social justification is a move away from the Court's proper role of protecting guaranteed rights, Justice McLachlin later supported the reconciliation process in Delgamuukw. As recalled from above, the reconciliation process in Delgamuиkw set conditions so demanding as to make it unimaginable how Aboriginal peoples can protect their own title to land.

Ultimately, the expanded role assumed by the Court in importing new criteria and considerations into section 35(1) is stupefying considering that Canadian courts are not even given a role in the reconciliation process as outlined in the Report of the Royal Commission on Aboriginal Peoples [RCAP]. RCAP looks toward "the full participation of the federal government, the provinces and the Aboriginal peoples" to devise "a national policy of reconciliation and regeneration of which we can all be proud." Court has lost the naked racism found in past precedent ${ }^{45}$ but has retained the language of domination, superiority and, in reference to Binnie's declaration of "collective sovereignty," assimilation. The Court is establishing a clear dominance between cultures. In Delgamииkw, reconciliation sanctions non-Aboriginal culture to act in ways that directly infringe upon the Aboriginal connection to the land. At the same time, Aboriginal cultures are forced to accommodate the colonizer's common law, assertions of sovereignty and the needs of broader society. While the Court couches the extensive list of possible grounds of justified infringement in the notion that Aboriginal communities are part of the broader Canadian landscape, the Court does not rationalize this assumption. Aboriginal people sue or defend themselves as Aboriginal peoples and they look for protection for their Aboriginal rights under section 35(1). In such a context, the Court should not reject Aboriginal rights based on "collective sovereignty" or the broader needs of society.

43 Van der Peet, supra note 12 at para 309.

44 Report of the Royal Commission on Aboriginal Peoples, [RCAP] Volume 1, Part One, Chapter 7.2, online:Indian and Northern Affairs Canada <http://www.ainc-inac.gc.ca/ch/r-cap/sg/sg19_e.html\#60>.

45 See e.g. Justice Patterson's decision in R. v Syliboy [1929] 1 D.L.R. 307 (N.S. Co. Ct.), where he discusses the capacity of "savages" to enter into a treaty. For further examples see D'Arcy Vermette "Colonialism and the Process of Defining Aboriginal People", (2008) 31 Dal LJ 211. 


\section{RECONSIDERING RECONCILIATION?}

The development of reconciliation has primarily taken place with regard to the identification, protection and limitation of Aboriginal rights. As discussed in this section, the Supreme Court has more recently used the principle of reconciliation in connection with Crown duties. Holding the Crown to a standard of conduct, through the imposition of duties owed to Aboriginal peoples, is a positive development. While the adequacy of these standards can be debated, the application of legal duties allows Aboriginal/Crown disputes to engage the issues beyond the isolated legal dispute at hand. Perhaps this is a way past the "element of insularity about the Court's approach to the concept of reconciliation." ${ }^{46}$ As an adjudicator of legal rather than political disputes, the Supreme Court will always remain, at its best, only part of the solution. In that sense it will remain somewhat insulated from the broader storm of Aboriginal/Crown disputes. However, without reflection upon the historical, cultural, and political dimensions of the issues at hand, the Court can become a barrier to justice rather than a path to access it. It is necessary for the Court to show flexibility and to ensure that it is accepting of the entire landscape of Aboriginal disputes with the Crown. ${ }^{47}$

As I argued above, the concept of reconciliation has allowed the Court to remain focused on the various ways in which Aboriginal people can accommodate the legal apparatus and norms of the colonizer. ${ }^{48}$ But moving beyond conception to practice, are the duties upon which the Supreme Court relies any more capable of building a path to reconciliation? I would argue that, so far, they are not.

For example, in Haida, ${ }^{49}$ the Supreme Court found that there can be a duty to consult with Aboriginal peoples prior to final claims resolution. This duty can also give rise to a duty to accommodate Aboriginal interests. ${ }^{50}$ The Supreme Court has asserted that the duty to consult requires that the Crown act in an honourable manner which affects the reconciliation "between the Crown and ... Aboriginal peoples" by balancing "societal and Aboriginal interests." Here the Court states: "The Crown may be required to make decisions in the face of disagreement as to the adequacy of its response to Aboriginal concerns. Balance and compromise will

46 Walters, supra note 13 at 176 . Walters describes the Supreme Court's insularity as follows: "It has not considered that concept in light of Aboriginal traditions or the early Crown-Aboriginal treaty relationship. Little or no reference has been made to the emergence of reconciliation within political discourse in Canada. And no mention has been made of the increasing importance of reconciliation to post-conflict situations in other countries, or to the expanding literature on this topic in political science and political theory."

47 For an examination of some of the ways in which Aboriginal peoples voices are underrepresented in the colonial judicial process, see D'Arcy Vermette, “Colonialism and the Suppression of Aboriginal Voice" (2009) 40:2 Ottawa L Rev 225.

48 Gordon Christie, "Delgamuukw and the Protection of Aboriginal Land Interests" (2000-2001) 32 Ottawa L Rev 85 (Q.L.) at para 40, where he writes: "the principle of reconciliation plays out in measures designed to integrate the Aboriginal community into the greater community. For the Crown to satisfy its fiduciary duties to Aboriginal peoples post-Gladstone, the Court requires no more than efforts to work Aboriginal peoples into the greater social, political and economic life of Canada."

Haida Nation v British Columbia (Minister of Forests), 2004 SCC 73 [Haida].

50 Ibid at paras.16-25 where it is explained that the duty to consult and accommodate is rooted in the principle of "the honour of the Crown".

$51 \quad$ Ibid at para 45. 
be necessary." ${ }^{52}$ The Court seems to be divesting itself of the responsibility to reconcile competing claims and, instead, placing this responsibility solely upon the Crown. The problem with such an approach is that the Crown is not in a position to make such a determination with any degree of neutrality or objectivity. ${ }^{53}$ By calling upon the Crown to make final decisions, which are intended to reconcile competing interests, the Court is disregarding $R C A P$ 's call for full participation of Aboriginal peoples. In the context of the duty to consult and accommodate, Haida clearly illustrates that the imposition of Crown authority upon Aboriginal rights remains strong. It is a position which remains fundamentally colonial.

More recently, the Supreme Court's refusal to engage the principle of reconciliation has helped to illustrate how this legal principle functions. $R . v$ $\operatorname{Kapp}^{54}$ was a section 15 equality challenge brought by non-Aboriginal fishermen who challenged a twenty-four hour exclusive fishery designated for Aboriginal fishing. In rejecting the argument challenging the exclusive Aboriginal fishery, the majority decision does not talk about the reconciliation of non-Aboriginal rights with Aboriginal rights. Prior to Kapp, the Court recognized that " $[\mathrm{r}]$ econciliation is not a final legal remedy in the usual sense. Rather, it is a process flowing from rights guaranteed by s. 35(1) of the Constitution Act, 1982." exclusive Aboriginal fishery was established as part of this process. In Kapp, the Supreme Court felt no need to pursue reconciliation as part of its reasoning. Why is it essential that the Supreme Court conduct reconciliation when Aboriginal rights are at issue but reconciliation is not to be conducted when the assertion is about the infringement of non-Aboriginal rights? This answer is as disturbing as it is unrelenting: the continued colonization of Aboriginal peoples.

In getting at this answer, let us consider first McNeil's scathing criticism of the Court's reconciliation process. Chief Justice Lamer's conception of reconciliation which has become the standard practice for the Supreme Court was assessed by McNeil as follows:

...he used it primarily to justify unilateral infringement of Aboriginal rights for the benefit of other Canadians...But if social harmony and peace depend on violation of the constitutional rights of the Aboriginal peoples, what does this say about Canadian society? Are non-Aboriginal Canadians really so mean-spirited? Would we accept violation of our constitutional rights because respect for them might threaten social harmony? Would we not seek to achieve social harmony and peace in ways that did not involve violation of fundamental rights? ? $^{56}$

52 Ibid.

53 Also see, Christie, supra note 48 at para 36 where he writes: "How is it that the Crown, held by the Court to be in a fiduciary position vis-à-vis Aboriginal rights-holders, is licensed to determine courses of action potentially impacting on the rights of these beneficiaries on the basis of measurements involving third parties?"

R. v Kapp, 2008 SCC 41.

55 Haida, supra note 49 at para 32.

$56 \quad$ McNeil, supra note 10 at 17. 
It is clear that the Supreme Court does not consider Aboriginal rights as fundamental rights. The Court has failed to imbue section 35(1) rights with the type of values in which all Canadians can take pride. Aboriginal rights are imbued instead with conflict, rather than framed in a spirit of responsibility. McNeil's question about "our" rights is pertinent here. The rights enshrined within the Constitution exist for the benefit, burden and (to pursue) the collective good of all Canadians. However, the failure of the Courts to effectively honour the obligations in section 35(1) is not a matter of being mean-spirited. It is a matter of being unwilling to make every effort possible to release itself from the processes of colonialism and domination with which Canadian law has grown accustomed. This is evidenced through the Court's unfounded assumption that Aboriginal rights need to be subject to limitation. ${ }^{57}$ The reason why reconciliation is essential for Aboriginal rights, and not for non-Aboriginal claims on the opposing side of the debate, is that the Court does not hold Aboriginal rights in the same esteem as non-Aboriginal rights. Non-Aboriginal rights are held in higher regard and therefore, the Court does not invent or apply arbitrary principles to justify infringing upon them. ${ }^{58}$

Another way in which the Supreme Court selectively uses the doctrines of reconciliation can be found in the recent decision of Little Salmon. Little Salmon which involves the application of the duty to consult in a modern land claims agreement is important because of its timeliness and because of its content (or lack of content) concerning reconciliation. When the Court in Little Salmon dealt with the issue of the duty to consult they revealed the complicit nature of their role in the colonial machine. That role, which was restated in Sparrow, involves ensuring that the colonizing state can operate with all the impunity that it needs in order to carry out its agenda. It is worth recalling that the Supreme Court said in Sparrow that "there was from the outset never any doubt that sovereignty and legislative power, and indeed the underlying title, to such lands vested in the Crown." ${ }^{.59}$ When you combine this list of fallacies with the ways in which legislative power is reinforced in Aboriginal rights discourse (through the doctrine of reconciliation) it is easy to see how a modern land claims agreement will only ever accrue very limited benefits. Still worse is the alternative. Because the Court has consistently reinforced legislative control, Aboriginal interests are doomed unless they do gain a measure of certainty via these modern agreements. It is only when one is immersed in the colonial condition that they would call the benefits attained by the First Nations in the Little Salmon/Carmacks First Nation Final Agreement a "balance of interests" ${ }^{\text {"60 }}$ or as "substantial.","

57

58

Similarly, Larry Chartrand, supra note Manitoba Act, 1870 (1985), 19 D.L.R. (4 $\left.4^{\text {th }}\right) 1$ and comments that "In other contexts where constitutional rights have been violated outside the Charter, the Supreme Court of Canada did not feel compelled to 'read in' a means for the government to nonetheless justify its infringement."

Sparrow, supra note 7 at para 49.

Little Salmon, supra note 8 at para 36-39.

1 Ibid at para 36. And, at para 9 Binnie describes these "substantial" and balanced interests: "Under the Yukon treaties, the Yukon First Nations surrendered their Aboriginal rights in almost 484,000 square kilometres, roughly the size of Spain, in exchange for defined treaty rights in respect of land tenure and a quantum of settlement land (41,595 square kilometres), access to Crown lands, fish and wildlife harvesting, heritage resources, financial compensation, and participation in the management of public resources." 
In Little Salmon, the Supreme Court fails to identify which conception of reconciliation they are using, although reconciliation is referred to repeatedly. ${ }^{62}$ Nonetheless, the colonial nature of the Court is revealed in two primary ways. First, in contrast to the interests of the First Nation, the Court misinterprets the role played by a Yukon resident who is seeking a grant of land within the trapping territory of the First Nation. Second, the absence of doctrine surrounding the Court's use of reconciliation shows us that, in the Court's conception, certain fundamental features of the Crown/Aboriginal relationship have already been reconciled. What and how the Court is willing to reconcile is equally as important as what it is not willing to reconcile.

A Yukon resident and potential private land owner had applied for a land grant within an area of surrendered territory which still carries the burden of the First Nation's hunting and fishing interests. Under the treaty the Crown has the ability to take up such lands from time to time. The main issue in Little Salmon is whether the Crown consulted adequately with the First Nation before granting the land to the Yukon resident. The Supreme Court found that the Crown did in fact discharge its duty to consult.

In determining that the Crown discharged its duty, the majority of the Court, via a decision written by Binnie, once again undermined the community interest of the First Nation. This is done by turning the First Nation into an individual. Binnie's decision contrasts the claim of the Yukon resident with that of the First Nation's trapper who had an entitlement over the lands which were to be granted to the Yukon resident. Binnie directs "considerable importance" to the existence of the claim of the Yukon resident. Further explaining, Binnie says that this application was made "as an ordinary citizen who was entitled to a government decision reached with procedural fairness within a reasonable time. ${ }^{, 64}$ Through this framework Binnie identifies the individual as the standard by which First Nations must adapt. This has damaging consequences for Crown/Aboriginal relations. In contrast to the "ordinary citizen," Binnie explains that "the entitlement of the trapper...was a derivative benefit based on the collective interest of the First Nation of which he was a member." ${ }^{\text {, }}$ The consequence is that Binnie does not feel that the trapper was entitled to represent his own individual interests in the consultation.

On the surface Binnie's conception seems to be giving primacy to the Aboriginal collective. However, in the context of this case he is actually undermining it. The venue of the consultation was the Land Application Review Committee, a committee which was established to handle applications for land grants. It was not a body designed to handle treaty disputes. As a result, one individual (who as an individual was not a party to the treaty) was granted the same procedural voice as a treaty partner (I will not pretend that the Court still views Aboriginal peoples as nations). Treaties were formerly used to exemplify

\footnotetext{
62 See e.g. ibid at paras. $12,40,45,52,55$, and at para 10 where the Court states: "The reconciliation of Aboriginal and non-Aboriginal Canadians in a mutually respectful long-term relationship is the grand purpose of s. 35 of the Constitution Act, 1982".

63 Ibid at para 35 .

64 Ibid.

65 Ibid.
} 
the relationship between the Crown and an Aboriginal People. ${ }^{66}$ Nowadays, if Little Salmon is illustrative, treaties merely represent the relationship between individuals and First Nations. It is necessary to point out that Aboriginal people as Aboriginal Peoples are not represented by the Yukon government (as Binnie contends). ${ }^{67}$ Further, Yukon residents are not voices of the Crown interest. Individual interests do not carry the same weight as that of the Crown or that of the First Nation. If the treaty is to be taken seriously, consultation between the treaty partners also has to be taken seriously. It is not enough to equate an Aboriginal community with an individual and call the duty to consult discharged:

the impact of an administrative decision on the interest of an Aboriginal community, whether or not that interest is entrenched in a s. 35 right, would be relevant as a matter of procedural fairness, just as the impact of a decision on any other community or individual ... may be relevant. ${ }^{68}$

It is with this type of comparison that we see that Binnie's attempt to assimilate Aboriginal people is truly taking shape within Aboriginal rights discourse. Binnie does state that "the First Nation here was consulted as a First Nation through the LARC and not as members of the general public." " However, the very next paragraph belies the truth of the reality that Binnie constructs. Binnie acknowledges that "[i]t is impossible to read the record in this case without concluding that the Paulsen application was simply a flashpoint for the pent-up frustration of the First Nation with the territorial government bureaucracy." ${ }^{, 70}$ Well, if that is the case why does the Crown not seek a solution which would provide a remedy?

The Crown then falls back on notions on administrative law to see if fair procedure was respected. Here notions of fairness are measured by what an individual might want: "the result of disallowing the application would simply be to let the weight of this cumulative problem fall on the head of the hapless Larry Paulsen (who still awaits the outcome of an application filed more than eight years ago). This would be unfair." The duty to consult is not a concept which can be delegated to a body which is actively engaged in determining the immediate material interests of individuals. To understand that consultation merely requires that an individual and the First Nation are granted equal opportunity to express

See for e.g. James [sakéj] Youngblood Henderson, "First Nations' Legal Inheritances in Canada: The Mikmaq Model" (1996) 23 Man LJ 1 at 5 where he writes: "These treaties ... united First Nations directly to the English crown as protected partners." And Simon v The Queen, [1985] 2 S.C.R. 387 at para 24, R. v Badger, [1996] 1 S.C.R. 771 at para 41 and RCAP, supra note 44 Vol. 2, Part One, Chapter 2, section 3.6 where the Commission writes: "The Commission uses the term 'spirit and intent' to mean the intentions the treaty parties voiced during treaty negotiations as the underlying rationale for entering into a treaty and its expected outcome: sharing, coexistence and mutual benefit."

Little Salmon, supra note 8 at para 33 where he writes: "The territorial government, elected in part by Aboriginal people, represents Aboriginal people as much as it does non-Aboriginal people, even though Aboriginal culture and tradition are and will remain distinctive." [emphasis added] 
their interests is to make a mockery of the process called reconciliation. In fact, it undermines the entire treaty process because it reduces the needs and interest of the First Nation to the same level of an individual. Individuals do not sign treaties with the Crown. Nor do First Nations cease to be First Nations (on par with the Crown as treaty partners) simply because they have signed a treaty.

This leads to my second concern with the Little Salmon case. There seems to be no concrete conception of what the Court means by reconciliation. The reason for this is clear. The Court assumes that the goal of the entire reconciliation process is legitimizing Crown occupation in Canada. Further it seems to be operating on the assumption that Aboriginal peoples are seeking, through treaty agreements, the amalgamation of their interests with other interest groups, all of which will be dealt with by the Canadian state. "In Canada, the top prize is cooptation: acceptance by the very club you are criticizing; which is not much of a basis for negotiation if you meant what you said in the first place." ${ }^{\text {"2 }}$ While the Court may state that reconciliation is an ongoing process even after modern treaties are settled, the ease with which it employs simple matters of administrative law to regulate the reconciliation process is illustrative of its ultimate contempt for the status of First Nations as nations. Rather than upset the government bureaucracy the Court forces accommodation and co-optation through the blind application of administrative law. In such a context the stage for reconciliation has been set by the particular methods described earlier in this paper as well as the false premises upon which the Court interprets treaty relationships. For post-treaty agreements the Court can now return to purely legal, rather than political, principles because it has found a way in which these principles now achieve the ultimate goal. The Court has found a way to this goal which pays attention to neither logic nor history but does appeal to the notions of conquest imbedded in the colonial mindset. In Little Salmon the absence of a coherent vision of reconciliation reveals that in the mind of the Court reconciliation has already arrived and its path can be found in the minutiae of Canadian law.

\section{CONCLUSION}

In the end, no matter which version of reconciliation the courts adopt, Aboriginal peoples are forced to deal with the same old clap trap of colonialism. Ultimately, the major development in Canadian law has been in the introduction and continued reliance on the word "reconciliation" itself. Through this word, courts can appear to be making progress while maintaining the status quo, producing yet another distraction to obscure the reality: Canadian courts are talking about and doing the same things to Aboriginal peoples that we more closely associate with (crimes of) the distant past. The judicial principle of reconciliation has been created out of thin air by the Supreme Court of Canada and applied in a manner which ultimately undermines the rights of Aboriginal peoples and continues to engage the colonization of Aboriginal peoples. But is it enough to say that reconciliation continues the colonial process? Can we appreciate what this means?

72 Edgar Friedenberg, Deference to Authority: The Case of Canada (New York: M.E. Sharpe Inc., 1980) at 25. 
The process and practice of colonialism necessarily involves the confiscation, theft, dispossession of Aboriginal peoples' lands, lives, and culture. This is not a mere inconvenience for Aboriginal peoples. Simply put, the law is contributing to the destruction of entire peoples. Colonialism only ends in two ways; either the colonizing State removes its tentacles from Aboriginal lives and lands, or it manages to accomplish the genocide of entire cultures. The Supreme Court of Canada's focus has remained steadfast in ensuring that the colonizing government (the Canadian state) retains control over Aboriginal people(s), resources, and governance. It is an all-encompassing venture and Canada's courts are not merely complicit in this process, they are an integral $\operatorname{cog}$ in the wheel. So, it begs the question, where is the justice and equality that should attend to constitutionally protected Aboriginal rights?

As the law currently stands, there is no justice and we have far too much work to do before we even begin talking about Canadian law bringing about equality. Hopefully, Canada's courts will wake up, take recognition of the damage they are doing, and begin to create law that empowers Aboriginal peoples to resist the dispossession being carried out in this continuing colonial process. One way to do this is to participate to the least extent possible. By simply recognizing and affirming Aboriginal rights the courts could stimulate a new era of negotiations. However, this is now very unlikely. Instead, chances are that, the courts will merely find a new word upon which to tie a seemingly new principle which will be designed to distract us from the process of dispossession which it has become accustomed to defending. Aboriginal peoples can, or should, be able to see through the nonsense of reconciliation brought to us by the courts.

Chrisjohn and Bear Nicholas have assessed the Federal government's attempt at reconciliation in the context of residential schools. Their words are equally relevant to the government's apology as they are to the Court's legal doctrine: "we've been witnessing a made-up ceremony, one where the participants, for various reasons, are trying more to convince themselves they've dealt with all the serious issues rather than actually putting an end to them." ${ }^{, 73}$ The Courts have made a mockery of the Constitutional protections afforded to Aboriginal peoples. It must be remembered that "protection which denies respect is no protection at all." lack of respect stems from the Court's insistence on using rhetoric rather than reasoning. And so it is that we go round and round. We become dizzy (and tired) from the various uses of language and empty doctrine that the courts throw at our peoples. Perhaps colonial powers are banking on us getting confused (or giving up) and losing sight of the access being granted to our lands and resources for the benefit of corporations and governments. Those diligent and dedicated enough to examine this legal nonsense are not confused by it. We are tired of looking at it, analyzing it, and having to unpack the same baggage over and over. But we are not confused.

Supra note 5.

Friedenberg, supra note 72 at Front Jacket. 